\title{
A REPRESENTAÇÃO DE MAPAS DE PAISAGENS NA ESCALA REGIONAL: O EXEMPLO DA REGIÃO COSTA DO DESCOBRIMENTO (BAHIA)
}

\author{
The representation of landscape maps in regional scale: the \\ example of the discorvery cost region (Bahia, Brazil)
}

La representación de mapas de paisajes en escala regional: el ejemplo de la región costa del descubrimiento (Bahia-Brasil)

\section{Raul Reis Amorim}

Doutorado em Geografia pela Universidade Estadual de Campinas (Unicamp). Estágio de PósDoutorado em Geografia pela Unicamp. Instituto de Geociências (IG). Professor no Instituto de Geociências da Unicamp. Rua João Pandiá Calógeras, 51. Cidade Universitária. CEP 13.083-870. Campinas - São Paulo.

E.mail:raul_reis@ige.unicamp.br

\section{RESUMO}

A representação dos Geossistemas em mapas que a Geografia Russa-Soviética denomina de mapas de paisagem, adota diferentes unidades físico-geográficas, conforme a escala de análise. O objetivo deste trabalho é mapear os geossistemas em escala regional, adotando a concepção teórico-metodológica da Geografia Russa-Soviética. Para atender ao objetivo proposto elaborou-se o Mapa de Paisagens da Região Costa do Descobrimento, na escala 1:250.000. Os geossistemas foram compartimentados a partir da inter-relação dos dados referentes a geologia, solos, relevo, vegetação, clima, rede hidrográfica, além de mapas morfométricos como hipsometria e declividade. Verificou-se que o mapa de paisagens pode subsidiar propostas de planejamento ambiental e ordenamento do território, pois a dinâmica e evolução dos geossistemas é fundamental para subsidiar às ações da sociedade na apropriação dos recursos naturais, assim evitando catástrofes naturais e acidentes decorrentes da ação humana.

Palavras-chave: Geossistemas, Geografia Russo-Soviética, Paisagem.

\section{ABSTRACT}

The representation of Geosystems in maps, that Russian-Soviet Geography calls landscape maps, adopts different physical-geographic alunits, according to the scale of analysis. The objective of this work is to map the geosystems in regional scale, adopting the theorical-methodological conception of the Russian-Soviet Geography. In order to meet the proposed objective, it was elaborated the Landscape Map of Discovery Costregion (Bahia, Brazil) in the scale 1:250.000. The geosystems were compartment alized from the inter relation of data on geology, soils, relief, vegetation, climate, Hydrographic network, and morphometric map sofhy psometry and slope. It was found 
that Land scape Map can support proposals of environmental planning and territorial management, because the dynamics and evolution of the geosystems is essential to support the society's actions in the owner ship process of natural resources, preventing, thus, natural disastersand accidents resulting from the human actions.

Keywords: Geosystems, Russian-SovietGeography, Landscape.

\section{RESUMEN}

La representación de losgeosistemasen mapas, que la Geografíaruso-soviético llama de los mapas del paisaje, adopta diferentes unidades físico-geográfica, segundo la escala de análisis. Así, eseestudiotiene como base enlomapeamientoen una escala regional, de 1:250.000, y lasconcepciónes teórico-metodológicas de la Geografíarusa-soviética. Para alcanzarelobjectivopropuesto, se elaboróel Mapa de paisajes de la Región Costa de descubrimiento. Los geosistemasfueron compartimentados por la interrelación de datos acerca de la geología, suelos, relieve, vegetación, clima, red hidrográfica y mapas morfométricos como hipsometría y la pendiente. De esse modo, los mapas del paisajepuedenapoyarlaspropuestas de planificación ambiental y la planificación del territorio, porque la dinámica y evolución de losgeosistemassonesenciales para apoyarlasaccionessocialesen la apropiación de los recursos naturales, evitando así que los desastres naturales, tales como lasinundaciones, los movimentos de masa y la erosión.

Palabras-claves: Geosistemas; Geografíaruso-soviético; Paisaje.

\section{INTRODUÇÃO}

O estudo da paisagem apresenta diferentes concepções a depender do foco de análise. Sochava, Krauklis e Snytko (1975) afirmam que um dos conceitos-chaves para o estudo da paisagem é o de geossistema. Este conceito foi difundido a partir da tradução para a língua portuguesa por professores da Universidade de São Paulo dos trabalhos do francês Bertrand (1971) e do russo-soviético Sochava $(1977,1978)$. Conforme Cavalvanti (2013 p. 82) "existe uma diferença fundamental na concepção de geossistemas entre Bertrand e Sochava, ou seja, mesmo ambos utilizando a mesma epígrafe, apresentam concepções distintas da palavra”.

Ainda conforme Cavalcanti (2013, p. 57):

\footnotetext{
Ecossistemas, geossistemas, regiões naturais, ecorregiões, paisagens, biomas, complexos biogeocenóticos, complexos territoriais naturais e tantos outros termos tentam representar, nas acepções de distintos autores, a ideia de que existe uma ordem natural promovendo a organização da superfície terrestre a partir das relações entre seus elementos constituintes internos (rochas, solos, seres vivos, água, etc.) e alguns externos (sol, movimentos orbitais, atividade interna do planeta).
} 
Sochava, Krauklis e Snytko (1975) apontam que a terminologia e a definição dos conceitos relativos ao estudo da paisagem sofrem uma ambiguidade. Isto pode ser explicado pelo fato da ciência da paisagem ter evoluído de forma independente em vários países, como foco em aspectos diferentes e nem sempre com a mesma posição.

Sochava (1971) afirma que a partir dos anos de 1950 a geografia e a ecologia ficam mais próximas. Tal proximidade fez com que os estudos realizando por geógrafos sofreu mudanças, pois até então, estavam interessados principalmente no estudo de grandes regiões. Os estudos de áreas muito pequenas não foram consideradas como competência da geografia. A atenção dos ecologistas, por outro lado, estava focada precisamente sobre biocenoses específicas e geossistemas elementares. Problemas ecológicos de uma escala regional mais ampla eram geralmente deixados para a biogeografia. A pesquisa geográfica integrada numa na perspectiva dos geossistemas tem sido centrada cada vez mais na pequena unidade de paisagem denominada como fácies físico-geográficas, enquanto a ecologia passou a dar mais atenção aos problemas do ecossistema planetário, bem como biomas e biócoros numa escala mais ampla.

Para Sochava (1973) o geossistema é sistema aberto representado por hierarquia dos sistemas naturais que se estrutura como um todo lógico racional.

Os termos e conceitos relacionados à ciência da paisagem e àqueles associados aos geossistemas e ecossistemas estão todos inter-relacionados e devem constituir um todo lógico. Eles pertencem a uma única família de termos e estão projetados para estabelecer interligações, as regularidades da integração e a diferenciação de causalidades relacionadas aos fenômenos naturais (SOCHAVA, KRAUKLIS e SNYTKO, 1975).

Vale destacar que cada geossistema se situa num ponto do espaço terrestre (SOCHAVA, 1977). Observa que estes devem ser analisados como pertencentes a um determinado lugar sobre a superfície da Terra. Para esse autor, existem diferentes unidades sistêmicas da estrutura da paisagem e denomina o menor componente dessa estruturação como fácies ou geômero elementar, ou seja, uma unidade que apresenta atributos corológicos, morfológicos e funcionais próprios, como a ocorrência de trocas de matéria e energia.

A natureza passa a ser compreendida não apenas pelos seus componentes, mas principalmente pelas conexões entre eles, não apenas se restringindo à morfologia da paisagem e às suas subdivisões, mas priorizando a análise de sua dinâmica, sua estrutura funcional e suas conexões (SOCHAVA, 1978). 
Sabe-se que os Geossistemas sofrem alterações na sua dinâmica no tempo e espaço, conforme afirmação de Sochava (1977, p. 10):

A transição de geossistema, de um estágio temporal para outro, significa evolução (...). Numerosas manifestações da mobilidade de geossistemas, dentro dos limites do estágio de uma era (um estágio de evolução) constituem a essência de sua dinâmica. Esses movimentos, em muitos casos, são contrários, ou quase; em seu conjunto representam um importante fator da evolução dos geossistemas. No processo da dinâmica, os componentes naturais independentes revelam diferentes graus e índices de mutabilidade.

Considerando que num sistema de hierarquia, os geossistemas interacionam-se com os sistemas antrópicos para formar numa ordem superior, os sistemas ambientais (AMORIM, 2012). Desta forma, deve-se considerar que os geossistemas normalmente têm como referência, na sua estruturação dinâmica e organização, o tempo geológico (tempo da natureza), mas na atualidade, frente à intensiva e quase que instantânea ação antrópica sobre os sistemas antrópicos, os geossistemas se reestruturam segundo a velocidade das transformações dos sistemas ambientais. A alteração na estrutura, dinâmica, funcionalidade e organização dos geossistemas está diretamente influenciada por mudanças nos fluxos externos de energia que geram, como resultado, transformações de causas endógenas que aparecem em diferentes níveis de diferenciação do ambiente natural, no processo das manifestações dinâmicas do próprio geossistema. Um exemplo destas alterações pode ser observado quando, em decorrência da ação antrópica, os fluxos de matéria e energia que se integrariam ao geossistema, são alterados, podendo acelerar processos erosivos capazes de ocasionar uma evolução do relevo muito mais acentuada. Isso ocorre, por exemplo com a erosão costeira, onde a vazão e os sedimentos de uma bacia hidrográfica foram alterados em decorrência da construção de barragens e/ou o recuo de escarpas litorâneas e não apenas pelo solapamento da base pela ação marinha, mas também por significativa contribuição do escoamento superficial, acentuado pelo uso e ocupação da terra, que substituíram a mata nativa por pastagens (AMORIM, 2012).

Para Amorim (2012), os geossistemas, ao longo do tempo da natureza buscam atingir seu equilíbrio dinâmico, ou seja, reestruturam-se todas as vezes em que ocorrem mudanças em um de seus componentes, ou alteração nos fluxos de matéria e energia decorrentes de mudanças climáticas, alterações na dinâmica de estruturação e esculturação do relevo, evolução/modificação de biomas etc.

Este trabalho adota o conceito de geossistema proposto por Sochava (1977) que é definido como "formações naturais" que obedecem à dinâmica dos fluxos de matéria e energia, inerentes aos sistemas abertos que, em decorrência da ação antrópica, podem sofrer alterações na sua funcionalidade, estrutura e organização, pois a interferência 
antrópica pode alterar a entrada de matéria e energia, interferir no armazenamento e/ou na saída de matéria, modificando assim a entropia do sistema. Reitera-se que o estudo das formações naturais apresentou em trabalhos acadêmicos apresentam denominações distintas como geossistemas, geocomplexos, paisagens e complexos territoriais naturais (CAVALCANTI, 2013).

A Comissão Permanente sobre Mapas da Paisagem da Sociedade Geográfica da União Soviética no relatório elaborado por Vinogradov et al. (1962) afirmam que o tipo básico de mapa da paisagem é um mapa único, que apresente um propósito sintético geral, mostrando complexos geográficos de um dado conjunto (dependendo da escala). Os autores ainda destacam que Mapa de Paisagens, deve oferecer a base para o mapa da paisagem aplicado cujo conteúdo pode ser especializado para propósitos específicos, principalmente pela adição de índices analíticos (encostas superficiais, composição mecânica dos solos, profundidade do lençol freático etc.).

Sochava (1973) utiliza um termo diferente para tratar do mesmo tipo de mapeamento: os mapas do ambiente. Para o autor, estes mapas retratam elementos constituintes ou determinantes do ambiente em forma sistematizada como um todo lógico e, ultimamente, como uma hierarquia de sistemas. Sochava (1973) ainda destaca que a abordagem sistêmica desempenha um papel significativo na cartografia temática, e isso estaria começando na década de 1970 a ser reconhecido por alguns cartógrafos. Neste contexto, ele destacou que havia uma necessidade de uma evolução da cartografia aplicando os princípios da teoria sistêmica, na construção de mapas com propósitos especiais. Como exemplo, destaca-se já em execução na União das Repúblicas Socialistas Soviéticas, o mapeamento ambiental passou a ser baseado nas proposições fundamentais da Teoria dos Geossistemas, a teoria da produção territorial e a teoria dos sistemas espaciais da população (SOCHAVA, 1973).

Conforme o Vinogradov et al. (1962) distingue-se quatro grupos de Mapas das Paisagens dependendo da escala e, consequentemente, da categoria da unidade de área mapeada:

- Mapas detalhados, de grande escala (fácies), de escala de 1:10.000 ou maior, mostrando predominantemente fácies (ao dizer que mapas de uma dada escala mostram fácies, mostrando todas as categorias classificatórias das fácies, tais como espécies, classes e tipos; o mesmo aplica-se a objetos mapeados em outras escalas, tais como tratos (mestnost) etc.);

- Mapas generalizados de grande escala, ou mapas de tratos, da escala 1:10.000 até 1:100.000; 
- Mapas de média escala, da escala 1:100.000 até a escala 1:1.000.000, em que os objetos mapeados são localidades (mestnost), associações ou complexos de tratos (urochishche);

- Mapas de pequena escala, menores que 1:1.000.000, mostrando principalmente paisagens.

Os autores destacam que deve ser dada maior prioridade para mapas de média escala para a compilação de mapas da paisagem de Estados e países, frequentemente de 1:300.000 a 1:600.000. Considerando as dimensões continentais do território brasileiro (tão grande quanto a antiga União Soviética), um mapa de paisagem singular para amplo uso científico e prático do território brasileiro, a escala sugerida pelos autores é a de 1:1.000.000, assim como o sugerido para a URSS. Para os autores, a escala de mapeamento mais adequada para mapas de média escala é 1:300.000.

Tendo o exposto, este trabalho, tem como objetivo fazer uma primeira aproximação com uso do Processamento Digital de Imagens e do uso dos Sistemas de Informações Geográficas na elaboração de Mapas de Paisagem para as unidades físico-naturais, não considerando o atual estágio de antropização de cada unidade. Para avaliar como a ação antrópica altera os fluxos de matéria e energia que levam a evolução diferenciada dos geossistemas, considerando que os mesmos estivessem em seu estado natural (sem remoção da cobertura vegetal, alteração no uso e ocupação dos solos, extrativismo mineral, vegetal e/ou animal, dentre outras ações). Acredita-se que a elaboração de Mapas de Paisagens considerando as alterações antrópicas deverão ser uma etapa subsequente, que precisa de um ponto de partida para futuros trabalhos na aplicação desta proposta metodológica em âmbito nacional, que começam a ser aplicadas no Brasil apenas a partir dos anos 2000, no Nordeste Brasileiro a partir dos estudos de Rodriguez, Silva e Cavalcanti (2004); Cavalcanti (2010), Cavalcanti, Corrêa e Araújo Filho (2010); Cavalcanti et. al. (2010); Cavalcanti, Corrêa e Isachenko (2010) e Cavalcanti, Corrêa e Araújo (2011).

A delimitação e mapeamento dos geossistemasem média escala é importante, primeiro, porque é importante verificar a eficácia dessa metodologia para a construção de modelos que darão suporte estudos ambientais; segundo, pois, acredita-se que a escala de análise adotada, irá apresentar em diferentes níveis de detalhes as transformações decorrentes no uso e ocupação das terras, considerando, assim, os níveis de fragilidade ambiental para a área selecionada para o estudo, e terceiro, possibilitar ampliar as discussões teórico-metodológicas no que refere-se ao estudo integrado dos componentes físico-naturais da paisagem. 


\section{METODOLOGIA}

\section{ÁREA DE ESTUDO}

A Costa do Descobrimento está localizada na região sul do Estado da Bahia, englobando os municípios de Belmonte, Santa Cruz Cabrália, Porto Seguro e Prado (Figura 1).

A Região Costa do Descobrimento foi delimitada pelo Programa de Desenvolvimento Turístico do Nordeste, PRODETUR (1997), por apresentar singularidade no uso e organização espacial da sua zona costeira, comparada às demais regiões costeiras do estado: Região Costa das Baleias, Região Costa do Cacau, Região Costa do Dendê e Região Costa dos Coqueiros. Até meados dos anos 1970, os municípios que integram a região Costa do Descobrimento integravam economicamente a Região Cacaueira que, até o final da década de 1980, tinha na monocultura cacaueira sua base econômica. A crise da monocultura cacaueira levou à implantação de novas bases econômicas, como a industrialização de bens de consumo duráveis e não duráveis e a implantação da atividade turística (explorando os potenciais naturais e culturais).

Figura 1 - Mapa de Localização da Região Costa do Descobrimento (Bahia)

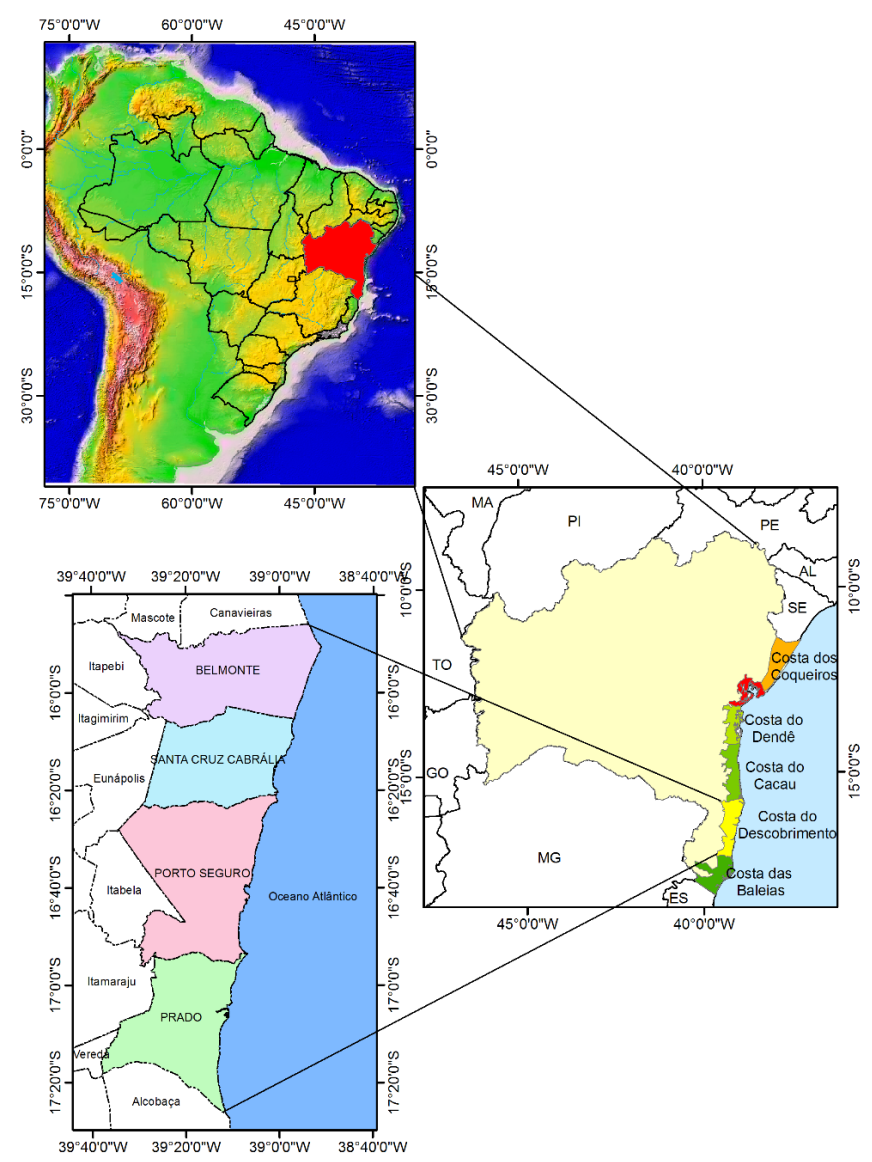

Fonte: CBPM (2000). Elaborado pelo autor. 
O uso e ocupação das terras ao longo da Região Costa do Descobrimento ocorre de maneira desigual, nos municípios de Porto Seguro e Santa Cruz Cabrália. Na faixa costeira, a expansão da área urbana é resultado da expansão imobiliária, principalmente vinculada à atividade turística, com a construção de cabanas de praia e pousadas ao longo da linha de costa, degradando as praias e devastando áreas de mangue e de vegetação de restinga. Dentre as ações ambientais mais frequentes destaca-se a degradação dos biomas costeiros, principalmente através de ações de aterro, desmatamento, despejo de efluentes e de lixo doméstico. Na porção mais ao interior desses municípios, a expansão da silvicultura de eucalipto e a inserção de algumas práticas agrícolas como a produção de cana-de-açúcar, mamão e café tem dinamizado as atividades econômicas ligadas ao setor rural desses municípios, que tinham na pecuária extensiva sua principal atividade econômica.

Já nos municípios de Belmonte e Prado, onde a atividade turística é incipiente, a ação antrópica tem atuado de maneira mais intensa na porção mais ao interior, principalmente a expansão da silvicultura de eucalipto na última década. $\mathrm{Na}$ faixa costeira, os biomas apresentam-se preservados, mas os sistemas ambientais costeiros apresentam-se em desequilíbrio em decorrência da construção de sistemas de engenharia de grande porte, como a Hidrelétrica de Itapebi, construída na Bacia do Rio Jequitinhonha, a montante do município de Belmonte, que vem alterando a deriva litorânea de sedimentos, e o que tem ocasionado processos erosivos costeiros de grande intensidade.

\section{FUNDAMENTOS TEÓRICO-METODOLÓGICOS}

Para a construção de mapas dapaisagem é importante definir padrões de representação a depender da escala a ser mapeada. Para Sochava (1977), não é a extensão territorial de representação dos fenômenos que irá determinar os táxons, mas sim a sua homogeneidade e/ou heterogeneidade. Desse modo, os Geossistemas taxonomicamente podem ser representados a partir dos geômeros e dos geócoros, conforme Figura 2 (SOCHAVA, 1971). O autor define os geômeros como Geossistemas com estrutura homogênea (a biogeocenose), enquanto os geócoros são Geossistemas com estrutura heterogênea. 
Figura 2 - Ordem de Geossistemas e subdivisões topológicas da paisagem
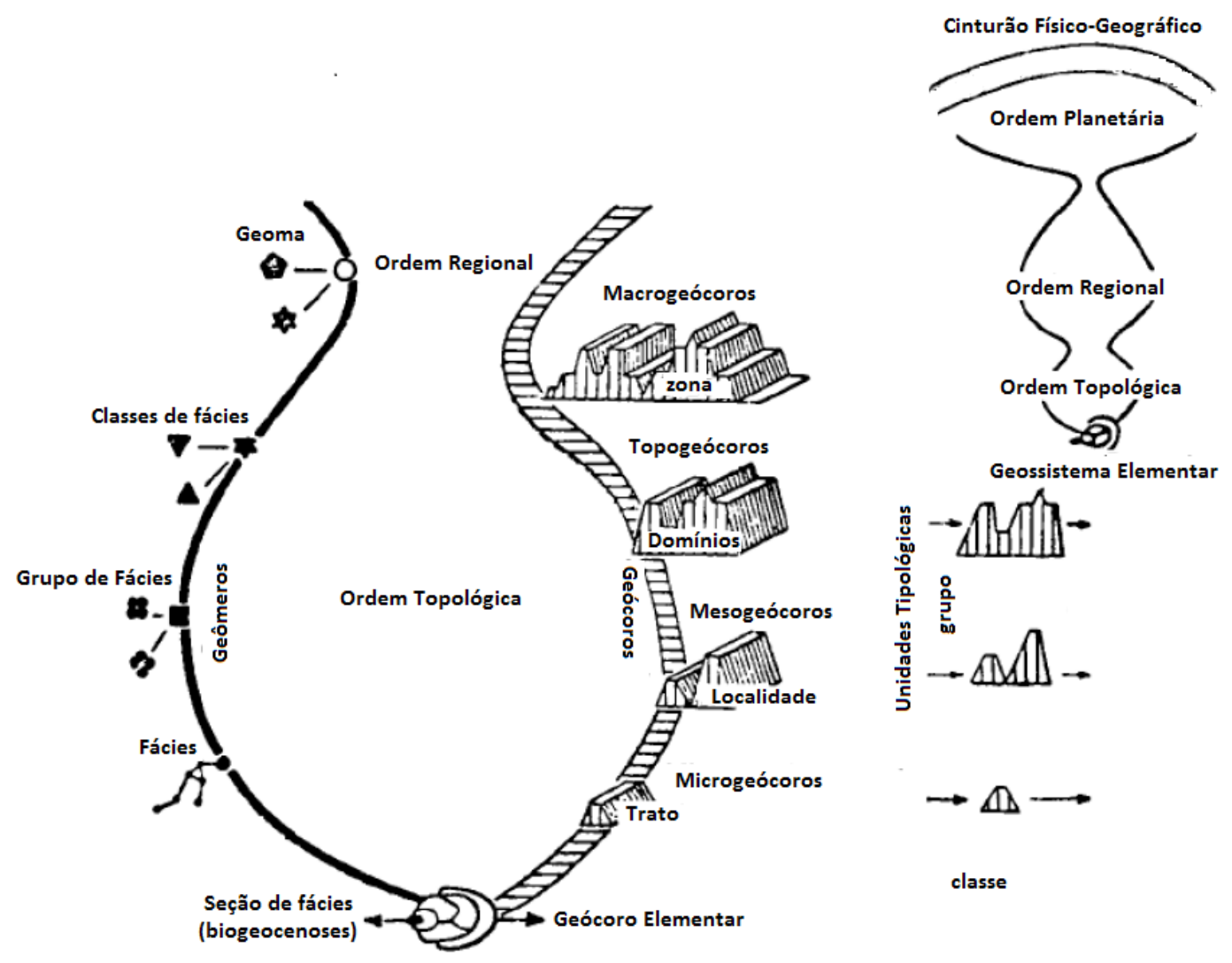

Fonte: Sochava (1971) - tradução livre do autor

Ainda sobre a taxonomia dos Geossistemas, Sochava (1977, p. 26-27) diz:

A classificação deveria: refletir, claramente, a hierarquia das subdivisões no âmbito das paisagens existentes na natureza; fornece uma ideia sobre as unidades naturais homogêneas das diversas categorias e, simultaneamente, sobre as unidades espaciais de diferentes qualidades co-subordinadas entre si, formando também uma categoria integral.

A taxionomia dos Geossistemas (...) é constituída segundo duas classes: uma de geômeros e outra de geócoros. (...) Essas classes, ao mesmo tempo em que são independentes, também se intercondicionam em liames nodais. Nos limites da ordem planetária de Geossistemas, as sequências de tipos de ambientes naturais (...) são adequadas às zonas físico-geográficas. As subclasses de geômeros, muito frequentemente, se avizinham dentro dos domínios das regiões físico-geográficas.

Sochava (1978) concebe que há três ordens dimensionais de análises nos estudos dos Geossistemas, a saber: a planetária, a regional, e a topológica. Cada uma apresenta uma escala e uma dinâmica particular de análise, mas que, ao mesmo tempo, interagem. 
A este respeito, o autor ainda afirma:

$\mathrm{Na}$ caracterização do meio natural verifica-se a convergência de dois princípios; homogeneidade e diferenciação. No processo de desenvolvimento natural desse domínio funcionam ao mesmo tempo os processos de homogeneidade e diferenciação. Todas as classes de Geossistemas com estrutura homogênea chamam-se "geômeros", e os de estrutura diferenciada são chamados de "geócoros" (SOCHAVA, 1978, p. 4).

O reconhecimento de áreas homogêneas no espaço geográfico, como as biogeocenoses, por exemplo, devem ocorrer de maneira coerente, admitindo uma análise generalizada, considerando a sua relação ecológica potencial ou seu ritmo natural (SOCHAVA, 1977).

Afirma ainda Sochava (1977) que a avaliação da homogeneização em diferentes graus de precisão pode se basear em estudos experimentais e observações visuais, subsidiando assim a classificação do Geossistema. Ressalta que apenas os estudos experimentais e as observações visuais não classificam o Geossistema de forma absoluta, sendo necessária a realização de adaptações e aperfeiçoamentos.

Vinogradov et al. (1962) apontam que os levantamentos da paisagem são mais eficazes quando associados com o uso de fotografias aéreas. Os autores apontam que isso acelera bastante o trabalho e aumenta a precisão, tanto em pesquisas de área quanto em levantamentos de campo transicionais. A interpretação de fotografias aéreas é, além disso, o melhor método para preenchimento no conteúdo do mapa da paisagem entre as rotas de campo transicionais. Este aspecto é útil porque torna possível destacar a rede de travessias necessárias e, portanto, reduz a necessidade de trabalhos de campo, enquanto que aumenta a quantidade de fotointerpretação no escritório. Cabe ressaltar, que na atualidade o custo e a disponibilidade de fotografias aéreas acabam dificultando o uso de tal sensor remoto, que a partir do desenvolvimento e aprimoramento das imagens de satélite, as fotografias aéreas passaram a ser substituídas por essas novas fontes de dados.

Conforme a proposta executada por Cavalcanti (2013) a partir dos estudos de Isachenko, os Geossistemas foram delimitados a partir do cruzamento dos limites dos Sítios e dos Estados. O autor determina como sítio, as relações entre relevo-substrato e como Estados, as relações solo-vegetação. Reitera-se que na proposta executada por Cavalcanti (2013), caso houvesse mais de um Estado por Sítio, o autor recomenda subdividi-lo.

Considerando que as escalas de mapeamento são iguais ou maiores que a 1:250.000, adotaremos os seguintes critérios de classificação dos sítios, apontadas por Cavalcanti (2013) conforme orientações de Isachenko (1973). 
1. Formas de Relevo - adotará a compartimentação das formas de relevo a partir de uma topossequência, tendo como auxílio a construção de perfis, no qual, as encostas foram subdivididas em topo, encosta superior, terço médio da encosta, base da encosta e áreas de acumulação.

2. Substrato - irá considerar as características gerais das formações superficiais, sejam sedimentos, mantos de alteração e ou perfis pedológicos representados nas cartas pedológicas e geológicas, para cada unidade de relevo. Adotar-se-á os seguintes tipos de substrato: Rochoso (quando for identificado nas cartas e mapas temáticos afloramentos rochosos); arenoso (quando predominar material com textura arenosa no material inconsolidado - indicativos são formações sedimentares e/ou classes de solos); argiloso (quando predomina material de textura argilosa no material inconsolidado indicativos são formações sedimentares e/ou classes de solos); e, pedregoso, quando no mapeamento utilizado, indicar-se na base das encostas a existência de depósitos de matérias não selecionados.

3. Gênese do substrato, que adotará dois tipos gerais: origem erosiva e origem deposicional. Cavalcanti (2013) destaca a importância de que quando não for possível inferir sobre a gênese do substrato, denomina-lo de indeterminado.

4. Rocha Matriz - rocha e/ou conjunto de rochas que deu origem ao substrato. Considerando que o mapeamento geológico a ser utilizado será de média e pequena escala, identificar com exatidão a rocha matriz que deu origem ao substrato não poderá ser aplicada, mais a formação, grupo, província ou complexo geológico, sim, uma vez que, os processos atuantes nesta gênese desse conjunto de rochas, apontam muito sobre seu comportamento nos processos intempéricos na paisagem.

\section{PROCEDIMENTOS METODOLÓGICOS}

Para atender aos objetivos propostos deste projeto de pesquisa, a primeira etapa foi a realização de uma revisão bibliográfica sobre a Teoria Geral dos Sistemas e a Teoria dos Geossistemas proposta por Sochava além de outras propostas metodológicas de regionalização físico-naturais, além de dados referentes aos aspectos físico-naturais da Região Costa do Descobrimento. Tal levantamento de dados ocorreu a partir de consultas dos periódicos, relatórios técnicos e teses e dissertações disponíveis nas bibliotecas online do país e exterior.

Outra etapa foi a definição das escalas taxonômicas a serem adotadas. Para atender aos objetivos propostos por este trabalho, foi necessária a construção de um banco de 
dados cartográfico para a representação cartográfica dos Geossistemas. Como o objetivo proposto para este trabalho foi a realização de uma análise integrada dos componentes físico-naturais da paisagem, foi adotada a escala 1:250.000 para a representação do mapa de paisagens da área em estudo.

Definida a escala taxionômica de trabalho, foi realizado o levantamento das cartas-base que abrangem os municípios em estudo. Foram selecionadas dez (10) Cartas Topográficas na escala 1:100.000 produzidas pela Superintendência de Desenvolvimento do Nordeste, SUDENE (1977): Canavieiras, Mascote, Potiraguá, Santo André, Porto Seguro, Salto da Divisa, Guaratinga, Monte Pascoal, Itamaraju e Prado.

Com a aquisição de tais cartas, foi realizado o escaneamento das mesmas, georreferenciamento em ambiente Arc GIS 10.3.1 e digitalização das variáveis pontuais (pontos cotados), lineares (curvas de nível, rede de drenagem e principais vias) e areais (limite dos municípios, áreas de inundação, lagos, rios de margem dupla, brejos). Tal recorte foi feito após a aquisição da delimitação dos municípios em ambiente digital (SEI, 2004).

Objetivando a elaboração do mapa de Paisagens da Costa do Descobrimento, foram descritos por ordem, os produtos cartográficos elaborados, organizados e/ou adaptados explicando os devidos procedimentos técnicos.

O primeiro documento cartográfico elaborado foi o Mapa Topográfico. Para tal foram utilizados os layes "curvas de nível com equidistância de 40 m”, "pontos contados", "áreas de inundação" e "limite municipal", já georreferenciados e digitalizados anteriormente. Inserem-se também as principais toponímias, como nome de localidades, cidades e municípios e nome dos principais rios. Esse mapa é representado na escala 1:250.000. O objetivo da organização deste documento cartográfico é a obtenção de informações para a elaboração do Mapa Hipsométrico e do Mapa Clinográfico em ambiente de SIG.

A partir do Mapa Topográfico foi possível elaborar o modelo digital de terreno que denominamos de Mapa Hipsométrico. Para gerar tal modelo foi utilizadoo software Arc GIS 10.3.1 no módulo ArcToolBox, na ferramenta Interpolação de Raster, no comando Topo para raster, e nele ocorreu a interpolação dos layes "curvas de nível", "pontos cotados" e "rede de drenagem", "lagos e rios de margem dupla" e "limite municipais", assim, gerando um modelo digital de terreno. Como a área apresenta uma variação altimétrica que vai de 0 a 480m, definiram-se dez (10) classes para melhor representação dos desníveis altimétricos da área, quais sejam: $\leq 25 \mathrm{~m}$; 25† 50m; 50† 100m; 100- 150m; $150 \nmid 200 \mathrm{~m}$; 200- 250m; $250-300 \mathrm{~m} ; 300-350 \mathrm{~m} ; 350-400 \mathrm{~m}$ e $\geq 400 \mathrm{~m}$. Este mapa foi elaborado a fim de identificar as áreas com maior desnível altimétrico, e as áreas de topos e nascentes. 
O Mapa Clinográfico foi gerado a partir do modelo digital de terreno com o uso do software Arc GIS 10.3.1 no módulo ArcToolBox na ferramenta Superfície para Raster no comando Declividade. Como a esculturação do relevo é essencialmente plana, pois na área predominam Tabuleiros Costeiros de topos planos e Planícies Fluviais, Fluviomarinhas e Terraços Marinhos, foram adotadas seis classes na tentativa de representar a variação de declividade da área. As classes definidas foram: $\leq 0,5 \% ; 0,5 \dashv 1 \% ; 1 \dashv 2 \% ; 2 \dashv 5 \% ; 5 \dashv 10 \%$; $10 \nmid 15 \% ; 15 \nmid 20 \%$ e $\geq 20 \%$. Como os levantamentos técnicos realizados por Brasil (1987), CBPM (2000), CPRM (2000) e a SEI (2004) afirmam que na área a declividade varia de 0,5 a 3\%, a variação de declividade não será uma variável considerada importante da diferenciação dos sistemas ambientais. Este Mapa é de fundamental importância nos estudos vinculados ao planejamento do uso e ocupação das terras, e também constitui um documento cartográfico que somado a outros mapas temáticos, pode identificar áreas com susceptibilidade a inundação e Movimentos de Massa.

Foi elaborado o Mapa de Compartimentação Geomorfológica na escala 1:250.000, resultante da análise visual de imagens de satélite RapidEye do ano de 2013 cedidas pelo Ministério do Meio Ambiente. A proposta deste mapa foi a delimitação dos principais compartimentos geomorfológicos da área em questão. Definiram-se três grandes compartimentos morfoestruturais: Os Maciços Cristalinos; os Depósitos Sedimentares Terciários e os Depósitos Sedimentares Quaternários onde, em cada Domínio Morfoescultural, identificaram-se as formas predominantes. Na Planície Costeira, encontram-se áreas de acumulação marinha, áreas de acumulação fluviomarinha e terraços marinhos. Já no Planalto Costeiro predominam os Tabuleiros Costeiros intercalados por fundos de vale e escarpas além de rampas de colúvios, enquanto no Planalto Pré-Litorâneo se identificam como formas predominantes colinas e morrotes, cristas e vales encaixados. Somados a elaboração do mapa de Compartimentação Geomorfológica, foram organizados, com o uso do software Arc GIS 10.3.1, o Mapa Pedológico elaborado por SEI (2004) na escala 1:250.000, o Mapa de Unidades Geológicas elaborado por CBPM (2000) na escala 1:100.000 e o Mapa de Cobertura Vegetal Natural elaborado por SOS MATA ATLANTICA (2014) na escala 1:50.000, que utilizou imagens Landsat 5 do ano de 2014 como fonte para a delimitação das áreas de Mata Atlântica, Restinga e Mangue. A análise desses mapas possibilitou compreender a inter-relação e a dinâmica dos atributos naturais na Região Costa do Descobrimento.

Além da produção cartográfica, buscou-se coletar dados climáticos, principalmente referentes à pluviosidade da área em estudo. Organizou-se em tabelas a distribuição das séries de dados pluviométricos dos últimos 40 anos das estações Belmonte, Santa 
Cruz Cabrália e Prado. Para o município de Porto Seguro, as séries históricas de dados pluviométricos apresentavam dados até o final dos anos de 1970 e retomadas em meados dos anos 2000 .

E, por fim, foi elaborado para cada área de estudo o mapa de paisagens com o uso do software Arc GIS 10.3.1, representando assim, os diferentes geossistemas da área em estudo.

No que se refere a legenda dos mapas de paisagens, Sochava (1973) afirma que a maioria dos produtos cartográficos que representam os geossistemas não são muito informativos e não tiram vantagem de todas as potencialidades gráficas. Algumas melhorias são claramente necessárias para aumentar a importância do método cartográfico no estudo dos Geossistemas. Simplesmente mostrando os limites dos Geossistemas em diferentes classes (frequentemente geócoros, mas, até certa medida, também geômeros) não podem ser considerados como um produto cartográfico final mesmo se os mapas se diferenciem entre limites bem definidos e não tão bem estabelecidos. Tal mapa é mais apropriado para servir como um "pano de fundo" para mostrar as ligações sistêmicas, particularmente para os componentes críticos dos complexos mapeados.

Tendo o exposto, o grande desafio deste trabalho foi a construção uma legenda que possibilitasse apresentar tais ligações sistêmicas entre seus componentes como propõe Sochava (1973).

\section{O MAPEAMENTO DA PAISAGEM DA REGIÃO COSTA DO DESCOBRIMENTO}

Os Geossistemas presentes na Costa do Descobrimento devem considerar a complexidade da interação dos processos oceânico-continentais, no seu processo de formação, evolução e organização dos sistemas integrantes. As discussões propostas partirão dos compartimentos de relevo, seguindo a sugestão de Ross (1990, p. 12) "o entendimento do relevo passa, portanto pela compreensão de uma coisa maior que é a paisagem como um todo".

Considerando que a Região Costa do Descobrimento se situa na zona costeira, os Geossistemas costeiros devem ser estudados como produtos da interação de diversos fatores, como os aspectos geológicos, climáticos, pedológicos, geomorfológicos, fluviais, bióticos e oceanográficos. É importante ressaltar que a interação e a ação de cada um desses fatores variam de um setor a outro da costa, assim como a escala da variação temporal (TUREKIAN, 1968; CHRISTOFOLETTI, 1980; RICE, 1980; HOEFEL, 1998; e MUEHE, 2001).

$\mathrm{Na}$ área em estudo definiram-se onze (11) Geossistemas (Figura 3). Alguns aspectos devem são responsáveis pelos fluxos de matéria e energia dos Geossistemas da Região Costa do Descobrimento, destacando-se em primeiro lugar a sua inserção na faixa zonal 
de baixa latitude, o que lhes confere caráter tropical. Outro aspecto é a maritimidade que, ao ladoda latitude, assegura as características fundamentais do clima regional. O relevo, que também é um fator que influencia o clima, principalmente no que tange a distribuição da pluviosidade, na permanência e dinâmica das massas de ar, entre outros fatores, tem importância no que se refere às temperaturas médias da região, sempre superiores a $25^{\circ}$ C ao longo do ano, pois a região apresenta 90\% de sua área com altitudes inferiores a 200 m e declividades inferiores a $5 \%$.

A abundância das precipitações ao longo da costa atlântica representa um elemento fundamental na definição do quadro natural, condicionando a cobertura vegetal, a rede hidrográfica e a ocupação do solo. É o domínio da Mata Atlântica que, outrora, recobria toda a área.

Todos os Geossistemas da Região Costa do Descobrimento são dominados pelo clima superúmido $(A f)$, conforme Köeppen. O clima é definido como tropical quente e úmido, com cobertura vegetal de floresta, ou seja, as temperaturas médias mensais são superiores a $18^{\circ} \mathrm{C}$ e não há um só mês com índice pluviométrico médio inferior a $60 \mathrm{~mm}$, predominando chuvas no outono e inverno, com precipitações entre 1.400 e $1.800 \mathrm{~mm}$, sendo mais elevadas próximas à linha de costa (SEI, 1999).

A circulação normal da superfície é proveniente do centro de alta pressão do Atlântico Sul, de onde se originam os ventos do quadrante E (NE e SE) que atuam na área. Essa região é, entretanto, constantemente afetada pela passagem das frentes frias (FPA) provenientes do sul do continente, responsáveis pelo alto grau de pluviosidade durante todo o ano (SEI, 1999).

O clima superúmido, é na atualidade, o responsável pelos processos de esculturação da paisagem na Costa do Descobrimento, sendo que, durante o Cenozóico, as oscilações climáticas e os movimentos eustáticos foram responsáveis pela esculturação dos vales encaixados, das escarpas litorâneas e a presença dos terraços marinhos presentes na área em estudo. 
Figura 3 - Mapa de Geossistemas da Região Costa do Descobrimento (Bahia)
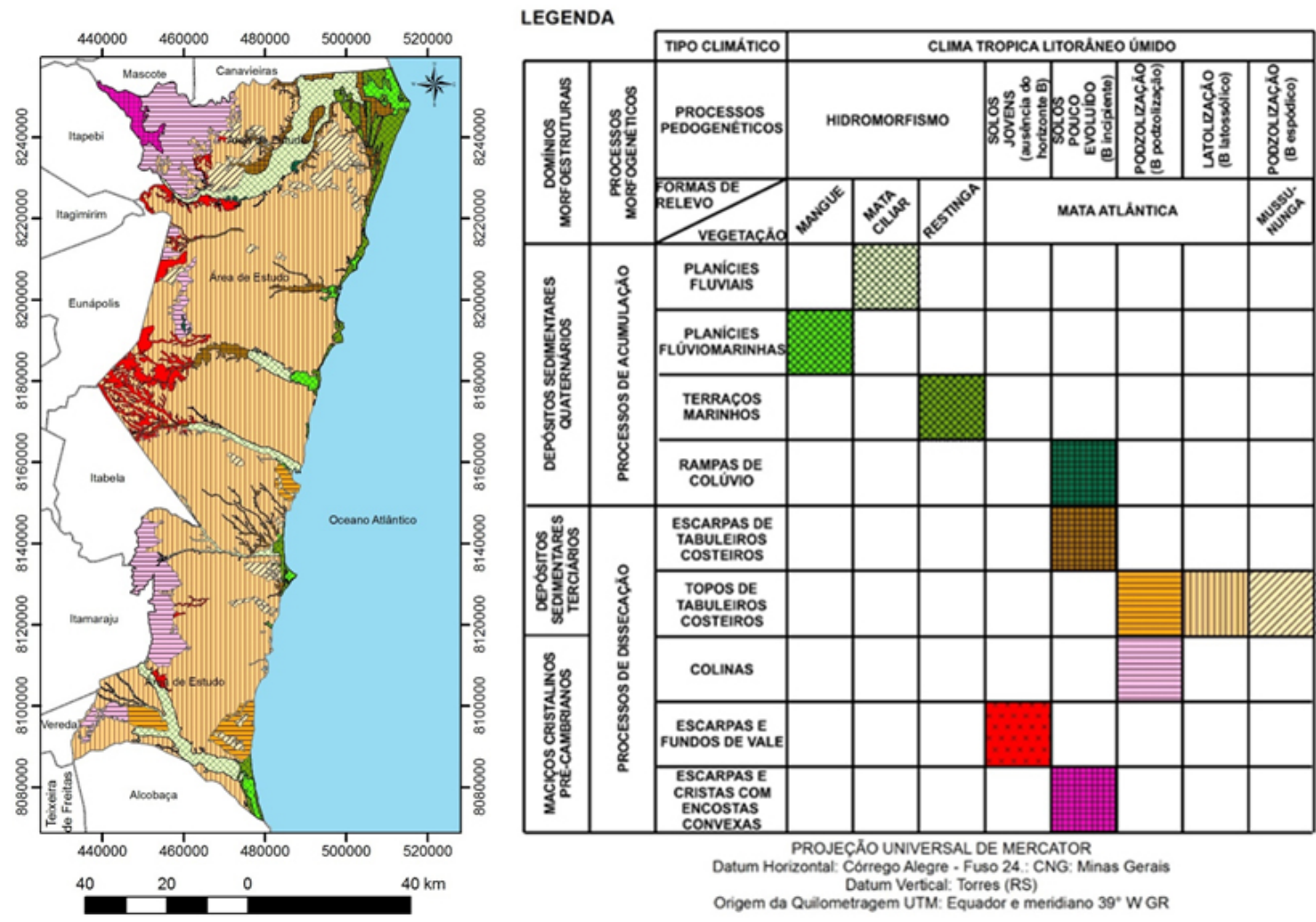

Elaborado pelo autor.

O Domínio Morfoestrutural Depósitos Sedimentares Quaternários forma as Planícies Quaternárias, constituídas por depósitos marinhos transicionais, depósitos de origem continental e recifes de coral e ocupa as áreas mais baixas da zona costeira, bordejando a linha de costa e adentrando os grandes vales escavados nos Tabuleiros Costeiros.

Nesse Domínio Estrutural, definiram-se três (03) Geossistemas transmissores e receptores de energia, pois estes se situam nas porções mais baixas da região. A ação do escoamento superficial e a ação erosiva fluvial são capazes de transportar e acumular matéria ao longo desses sistemas. Os processos predominantes são os deposicionais, decorrentes da ação fluvial (Planícies Fluviais), de processos marinhos (Terraços Marinhos) e de processos conjuntos da ação fluvial e marinha (Planícies Fluviomarinhas). Cabe ressaltar que, em decorrência da escala de representação, delimitaram-se dois (02) Geossistemas nas áreas de transição entre o Domínio Morfoestrutural Depósitos Sedimentares Quaternários e entre o Domínio Morfoestrutural Depósitos Terciários, ou seja, na área de contato entre as Planícies Fluviais mais tênues associadas a escarpas de Tabuleiros Costeiros, com vales mais encaixados. 
As Planícies Fluviais correspondem a áreas planas ou levemente inclinadas contendo sedimentos quaternários de textura, permeabilidade e coesão variáveis. Compartimentando a área em estudo, verificou-se que a área de Planícies Fluviais abrange uma área de 1.092,387 $\mathrm{km}^{2}$, o que corresponde a quase de $15 \%$ da área da região Costa do Descobrimento. A litologia nas planícies fluviais apresenta a seguinte composição: (a) depósitos de leques aluviais, (b) depósitos argilo-orgânicos, (c) depósitos areno-argilosos fluviais; e (d) depósitos de areias lagunares e estuarinas.

Alguns aspectos devem são responsáveis pelos fluxos de matéria e energia dos Geossistemas da Região Costa do Descobrimento, destacando-se em primeiro lugar a sua inserção na faixa

Os depósitos de leques aluviais ocorrem apenas na Planície Fluvial do Rio Jequitinhonha. Estes sedimentos são interpretados como resultado da deposição em leques aluviais no sopé das encostas da Formação Barreiras, em um período de clima mais árido que o atual.

Os depósitos argilo-orgânicos constituem os sedimentos que se acumularam em associação a áreas que são inundadas ou saturadas por água superficial ou água subterrânea, numa frequência e duração suficientes para dar suporte a uma vegetação tipicamente adaptada à vida em condições saturadas.

Os depósitos areno-argilosos fluviais são constituídos por sedimentos de diques marginais, de barras de meandros e de canais abandonados, que ocorrem em estreita associação com os principais rios que deságuam na região. As ocorrências mais expressivas destes depósitos são encontradas na planície fluvial do rio Jequitinhonha e na Planície do rio Jucuruçu.

Nesse Domínio Estrutural, definiram-se três (04) Geossistemas transmissores e receptores de energia, pois estes se situam nas porções mais baixas da região. A ação do escoamento superficial e a ação erosiva fluvial são capazes de transportar e acumular matéria ao longo desses sistemas. Os processos predominantes são os deposicionais, decorrentes da ação fluvial (Planícies Fluviais), de processos marinhos (Terraços Marinhos) e de processos conjuntos da ação fluvial e marinha (Planícies Fluviomarinhas) e as Rampas de Colúvio decorrentes dos processos gravitacionais que situam-se no limite entre as escarpas e as planícies fluviais. Cabe ressaltar que, em decorrência da escala de representação, delimitaram-se dois (02) Geossistemas nas áreas de transição entre o Domínio Morfoestrutural Depósitos Sedimentares Quaternários e entre o Domínio Morfoestrutural Depósitos Terciários, ou seja, na área de contato entre as Planícies Fluviais mais tênues associadas a escarpas de Tabuleiros Costeiros, com vales mais encaixados. 
As Planícies Fluviais correspondem a áreas planas ou levemente inclinadas contendo sedimentos quaternários de textura, permeabilidade e coesão variáveis. Compartimentando a área em estudo, verificou-se que a área de Planícies Fluviais abrange uma área de 1.092,387 $\mathrm{km}^{2}$, o que corresponde a quase de $15 \%$ da área da região Costa do Descobrimento. A litologia nas planícies fluviais apresenta a seguinte composição: (a) depósitos de leques aluviais, (b) depósitos argilo-orgânicos, (c) depósitos areno-argilosos fluviais; e (d) depósitos de areias lagunares e estuarinas.

Alguns aspectos devem são responsáveis pelos fluxos de matéria e energia dos Geossistemas da Região Costa do Descobrimento, destacando-se em primeiro lugar a sua inserção na faixa

Os depósitos de leques aluviais ocorrem apenas na Planície Fluvial do Rio Jequitinhonha. Estes sedimentos são interpretados como resultado da deposição em leques aluviais no sopé das encostas daFormação Barreiras, em um período de clima mais árido que o atual.

Os depósitos argilo-orgânicos constituem os sedimentos que se acumularam em associação a áreas que são inundadas ou saturadas por água superficial ou água subterrânea, numa frequência e duração suficientes para dar suporte a uma vegetação tipicamente adaptada à vida em condições saturadas.

Os depósitos areno-argilosos fluviais são constituídos por sedimentos de diques marginais, de barras de meandros e de canais abandonados, que ocorrem em estreita associação com os principais rios que deságuam na região. As ocorrências mais expressivas destes depósitos são encontradas na planície fluvial do rio Jequitinhonha e na Planície do rio Jucuruçu.

E os depósitos de areias lagunares e estuarinas são constituídos por areias de granulação média a fina, mal selecionadas, que ocorrem no interior de alguns dos grandes vales escavados nos tabuleiros costeiros, a exemplo dos vales dos rios Buranhém e dos Frades.

Nos sedimentos que compõem as Planícies Fluviais, instalam-se processos pedogenéticos que dão origem aos Neossolos Flúvicos de textura arenosa, areno-argilosa e argilosa, além de coluviões de textura variável incluindo localmente seixos e blocos queapresentam declividade extremamente fraca ( 0 a $2 \%$ ), favorecem o escoamento subsuperficial, que está ligado à variação de nível do lençol freático, elevado por ocasião das chuvas. Outras classes de solos associadas às Planícies Fluviais são os EspodossolosHidromórficos e os Neossolos QuartzarênicosHidromórficos. Nas escarpas de Tabuleiro Costeiro associadas às Planícies Fluviais podem-se identificar predominantemente os Cambissolos Háplicos associados a Latossolos Amarelos e/ou Argissolos Amarelos. 
A ocorrência dos Cambissolos evidencia um grande fluxo de material pelas escarpas e encostas íngremes, o que faz com que os horizontes superiores dos Latossolos Amarelos e/ou Argissolos Amarelos sejam removidos pela ação erosiva, instalando-se no material preservado um novo ciclo de pedogênese, no geral os processos pedogenéticos atuam no desenvolvimento do horizonte $\mathrm{B}$, ainda característico de solos rasos formando o horizonte B incipiente.

O processo morfogenético predominante é o escoamento superficial, que provoca processos erosivos laminares localizados, devido à ausência da cobertura vegetal natural, expondo assim as margens dos rios. Este processo aliado ao menor gradiente dos rios, que implica uma diminuição da sua competência, e a chegada de detritos provenientes das margens atingidas por desbarrancamentos, faz com que a maioria dos rios transporte grande quantidade desses detritos, por ocasião das grandes enchentes. Isso leva ao transbordamento do leito e consequente deposição nas margens e nas partes baixas dos terraços, fertilizando o solo e dificultando a evolução da pedogênese (BRASIL, 1987; SANTANA et al, 2002).

A cobertura vegetal predominante nas Planícies Fluviais é a mata ciliar, que é caracterizada por CBPM (2000) como uma formação vegetal ribeirinha que ocorre ao longo dos cursos de água. Essa formação é constituída de plantas de porte alto (20 a $50 \mathrm{~m}$ ), médio (20 a $30 \mathrm{~m}$ ) e baixo ( 5 a $20 \mathrm{~m}$ ), de rápido crescimento, em geral de casca lisa, tronco cônico, por vezes com forma característica de botija e raízes tabulares, apresentando muitas palmeiras no estrato intermediário. A retirada da mata ciliar das Planícies e a devastação da Mata Atlântica nos últimos 40 anos, na região, têm alterado os fluxos de matéria e energia, modificando a dinâmica desses sistemas naturais. A ação humana faz com que os Geossistemas situados nas Planícies Fluviais da Costa do Descobrimento procurem se rearranjar às novas condições ambientais, principalmente nos fluxos de matéria e energia que alteraram a dinâmica fluvial na área. Uma prova desse rearranjo está na modificação dos canais, ou pelo maior aporte de sedimentos e/ou menor disponibilidade de sedimentos depositados. No caso do Rio Jequitinhonha, observa-se modificações no padrão da drenagem e no formato dos canais entre 1974 e 2008. A Figura 4(A) e (B) mostram que, em 1974, o canal próximo ao delta do Rio Jequitinhonha apresentava-se mais sinuoso, com padrão meandrante, enquanto em 2008 o canal apresenta-se retilinizado.

Outra característica dos Geossistemas situados nas Planícies Fluviais da Costa do Descobrimento é apresentarem áreas com inundação periódica, onde as terras úmidas situam-se em áreas com declividades inferiores a $2 \%$, portanto as áreas mais baixas das Planícies Fluviais são particularmente, os grandes vales escavados nos Tabuleiros Costeiros. Nas bacias hidrográficas dos rios João de Tiba, Buranhém, rio do Frade, Rio Trancoso e Rio Caraíva, visualizam-se os vales encaixados de maior extensão. 
Figura 4 - Modificações no Padrão de Drenagem da Desembocadura do Rio Jequitinhonha entre 1974 (A) e 2014 (B), Belmonte (BA).
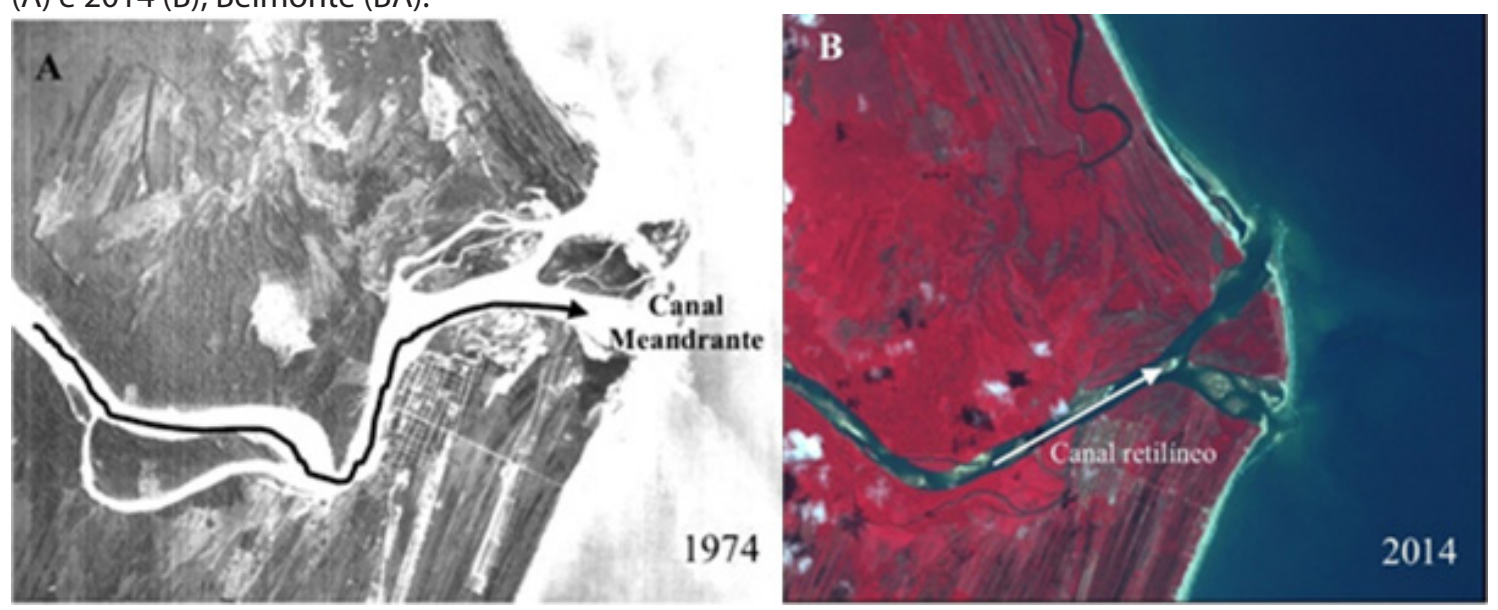

Fonte: (A) Fotografia área (Escala 1:60.000), CEPLAC; (B) Imagem RapidEye (abril/2014).

Nestas áreas se acumularam sedimentos argilosos ricos em matéria orgânica e, por vezes, camadas de turfa com espessura decimétrica. Em profundidade, esses depósitos de terras úmidas podem passar para sedimentos lagunares e estuarinos que se acumularam durante episódios de nível de mar mais alto que o atual. A cobertura vegetal que ocupa a área é denominada por CBPM (2000) como vegetação de brejo. As áreas inundáveis nem sempre têm sido consideradas como um recurso natural. Pelo contrário, estas áreas têm sido vistas como locais para serem drenados, aterrados ou dragados. Todavia as áreas inundáveis desempenham importantes funções ambientais, tanto do ponto de vista físico quanto biológico: (1) desempenham funções ecológicas críticas na reprodução, alimentação e descanso de aves aquáticas, de um modo geral, sendo de extrema importância para as aves aquáticas migratórias; (2) retêm água das chuvas, reduzindo a severidade das inundações nas áreas vizinhas. Elas também servem como tampões hidrológicos para reservatórios subterrâneos, liberando água nos períodos secos e armazenando-a nos períodos chuvosos.

Uma área que merece destaque é a Planície Fluvial da Bacia do Rio Jequitinhonha,que apresenta um sistema de produção agroflorestal, conhecido como "cabruca". Esta Planície, por ser mais ampla que as demais, permitiu o desenvolvimento de um complexo vegetal composto pela Mata Ciliar e pela MataAtlântica. O desenvolvimento de tal prática agrícola data do século XIX, quando os agricultores apenas substituíam os extratos inferiores da mata por pés de cacau. Tal prática agrícola possibilitou apenas a preservação dos extratos superiores da Mata Atlântica, substituindo a vegetação herbácea e arbustiva por pés de cacau. 
Verifica-se que a Mata Ciliar e os extratos mais baixos da Mata Atlântica foram substituídos pela lavoura cacaueira. A retirada da vegetação natural e a inserção de atividades econômicas, principalmente vinculadas à agricultura e a pecuária, expõem os solos aos processos erosivos, e consequentemente, acentuam o assoreamento dos rios.

Outro Geossistema identificado na área de estudo está vinculado aos Terraços Marinhos. Essas são áreas formadas por depósitos sedimentares de origem marinha, situados acima do nível médio atual (GUERRA e GUEERA, 2005). Na área em estudo, delimitou-se um Geossistema situado nos Terraços Marinhos, que ocupam o que poderia formar a Planície Marinha, pois, ao longo de toda a linha de Costa, a Planície Marinha é restrita à zona de arrebentação e a pós-praia é formada por níveis de Terraços Marinhos. A Figura 5 mostra o terraço marinho situado na bacia do rio Mogiquiçaba, onde a ação eólica está remobilizando os sedimentos e formando pequenas dunas. Vale ressaltar que a cobertura vegetal natural foi substituída, em alguns trechos, por plantações de coco-dabaía, voltadas para a comercialização.

Formaram-se os Terraços Marinhos Pleistocênicos, entre 6 e 8 metros, que se situam nas mediações das Planícies Fluviais dos Rio Jequitinhonha, João de Tiba, Corumbaú e Caraíva ou podem ser identificados nas linhas de paleofalésias esculpidas nos sedimentos da Formação Barreiras.

Figura 5 - Terraço Marinho na Bacia do Rio Mogiquiçaba com Remobilização Eólica, Belmonte (BA).

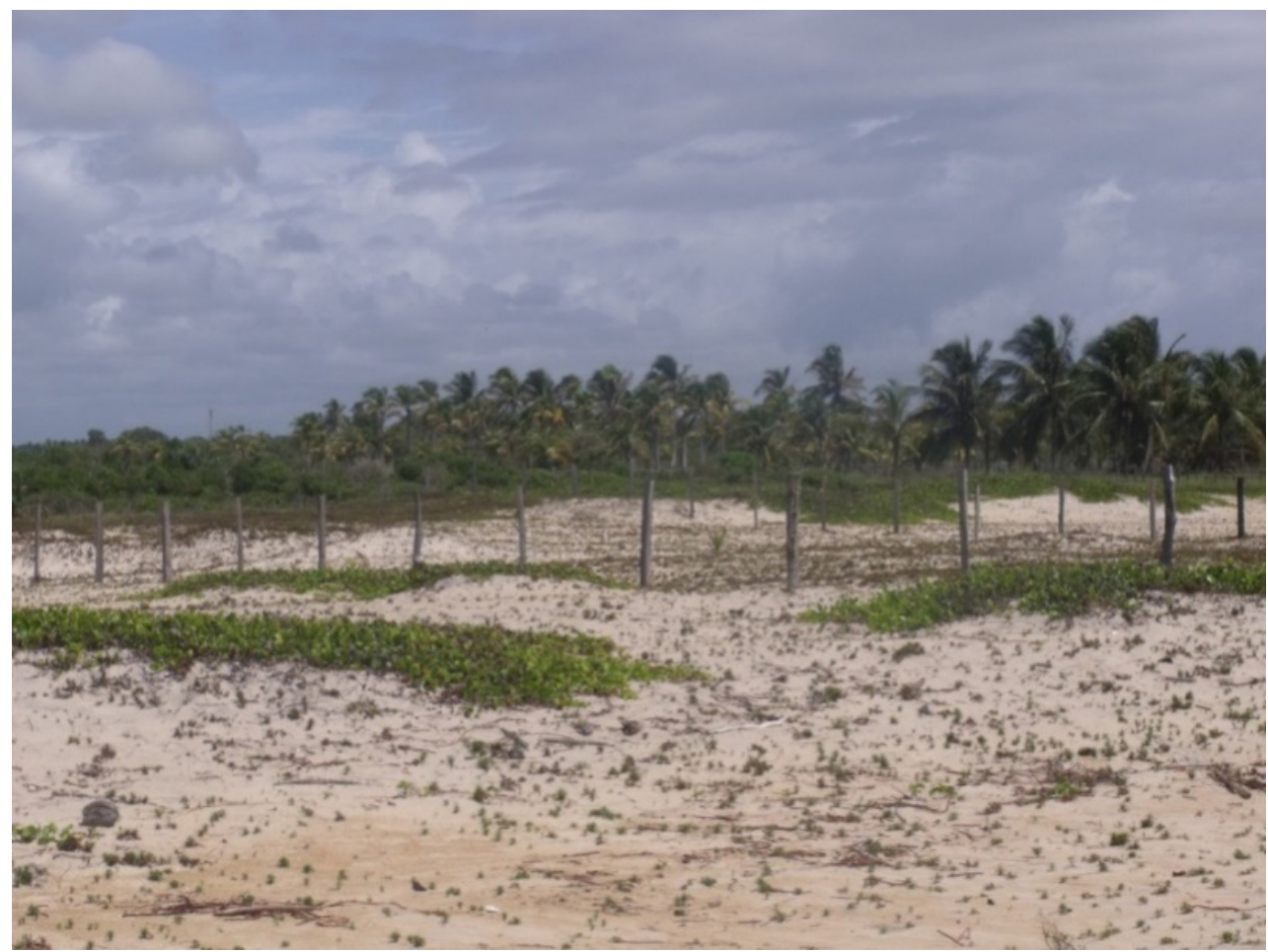

Fonte: Trabalho de campo (junho/2015) 
Os Terraços Marinhos Holocênicos estão situados a uma altitude que varia entre 4,5 a $5 \mathrm{~m}$. Sua superfície apresenta uma declividade em direção à praia atual, ocorrendo nas porções externas das planícies quaternárias. Tais Terraços podem fazer limite com os Terraços Marinhos Pleistocênicos ou acham-se separados destes por zonas deprimidas, antigamente lagunares. Encontram-se também, na região de Porto Seguro, Terraços Marinhos Holocênicos, que estão situados diretamente no sopé das falésias esculpidas nos sedimentos da Formação Barreiras.

Nos Terraços Pleistocênicos, segundo Suguio e Martin (1976), a origem marinha destes depósitos pode ser assegurada pela presença de tubos fossilizados de Callichirus, cuja zona de vida, no caso da espécie encontrada (Callichirus major), corresponde à zona da maré baixa. Esta origem é também confirmada por estruturas sedimentares singenéticas, tais como as estratificações cruzadas de baixo ângulo e espinha-de-peixe. Não foram encontradas conchas de moluscos preservadas nesses sedimentos, em consequência da dissolução dessas pelos ácidos húmicos. Tal ataque deu-se em decorrência da instalação dos processos pedogenéticos responsáveis pela formação dos Espodossolos encontrados na área. O horizonte superficial do solo apresenta coloração branca na superfície, e o horizonte subsuperficial, o B espódico, apresenta, em profundidade, comumente cores acastanhadas ou pretas, em consequência dos processos de translocação dos ácidos húmicos, que lhes confere também uma coesão moderada. Na superfície, existem vestígios de antigos alinhamentos de cristas praiais (cordões litorâneos) que apresentam características morfológicas muito particulares (MARTIN et al., 1981; SANTANA et al, 2002).

Como afirmam Martin et al, (1981), ao contrário do que acontece nos depósitos pleistocênicos, foi identificada nos depósitos holocênicos, a presença de conchas de moluscos que raramente são impregnados por ácidos húmicos. Além da presença de conchas de moluscos marinhos, a origem marinha desses depósitos pode ser assegurada pela existência de tubos fossilizados de Callichiruse por estruturas sedimentares típicas de ambiente praial. A partir da interpretação visual das imagens de satélite RapidEye pode-se observar que a superfície destes terraços é coberta de alinhamentos muito nítidos de antigas cristas praiais, cujas características são bastante diferentes das existentes na superfície dos terraços pleistocênicos. Destacam-se os Terraços situados na desembocadura da Bacia do Rio Jequitinhonha, nos quais o material marinho em períodos de inundação do rio, é sobreposto por material de origem fluvial e fluviomarinha.

$\mathrm{Na}$ área em estudo, os Terraços Marinhos correspondem a aproximadamente a $3,5 \%$ da área em estudo, com 240,00 $\mathrm{km}^{2}$, distribuídos nas bacias dos Rios Pardos, Caraíva, Corumbau, Mogiquiçaba, Queimado, Santo Antônio, Taípe, Barra, Buranhém, 
Jequitinhonha, Jucuruçu e dos Rios Costeiros de Coroa Vermelha. Destaca-se no terraço marinho situado na bacia do rio Mogiquiçaba o processo de remobilização eólica é responsávelpela formação de pequenas dunas. Vale ressaltar que a cobertura vegetal natural foi substituída, em alguns trechos, por plantações de coco-da-baía, voltadas para a comercialização.

Nos Terraços Marinhos encontra-se predominantemente a vegetação de Restinga, apresentando duas fisionomias: a arbórea e a herbácea. A sua formação florística é relativamente simples. As árvores e arvoretas, com altura em torno de $7 \mathrm{~m}$, apresentam copas bastante regulares, submata densa e certa abundância de epífitas. Em segundo plano, têm-se os cordões litorâneos propriamente ditos, raramente atingidos pelas marés, e que se denominam caméfitas e microfanerófitas (arbustos), caracterizando a vegetação de Jundu com estratificação Arbustiva (scrub). A densidade da vegetação é variável e sempre composta de um estrato herbáceo de espécies com caules estoloníferos, o que confere a esses cordões de pequenas dunas certa estabilidade (Figura 6). Os solos altamente salinos, aliados a uma temperatura elevada, manifestam-se através de algumas adaptações morfológicas, que influem na ação fisiológica das plantas, como caules estoloníferos e rizomas (BRASIL, 1987).

Figura 6 - Restinga Herbácea os Terraços Marinhos da Bacia do Rio Jequitinhonha, Belmonte (BA).

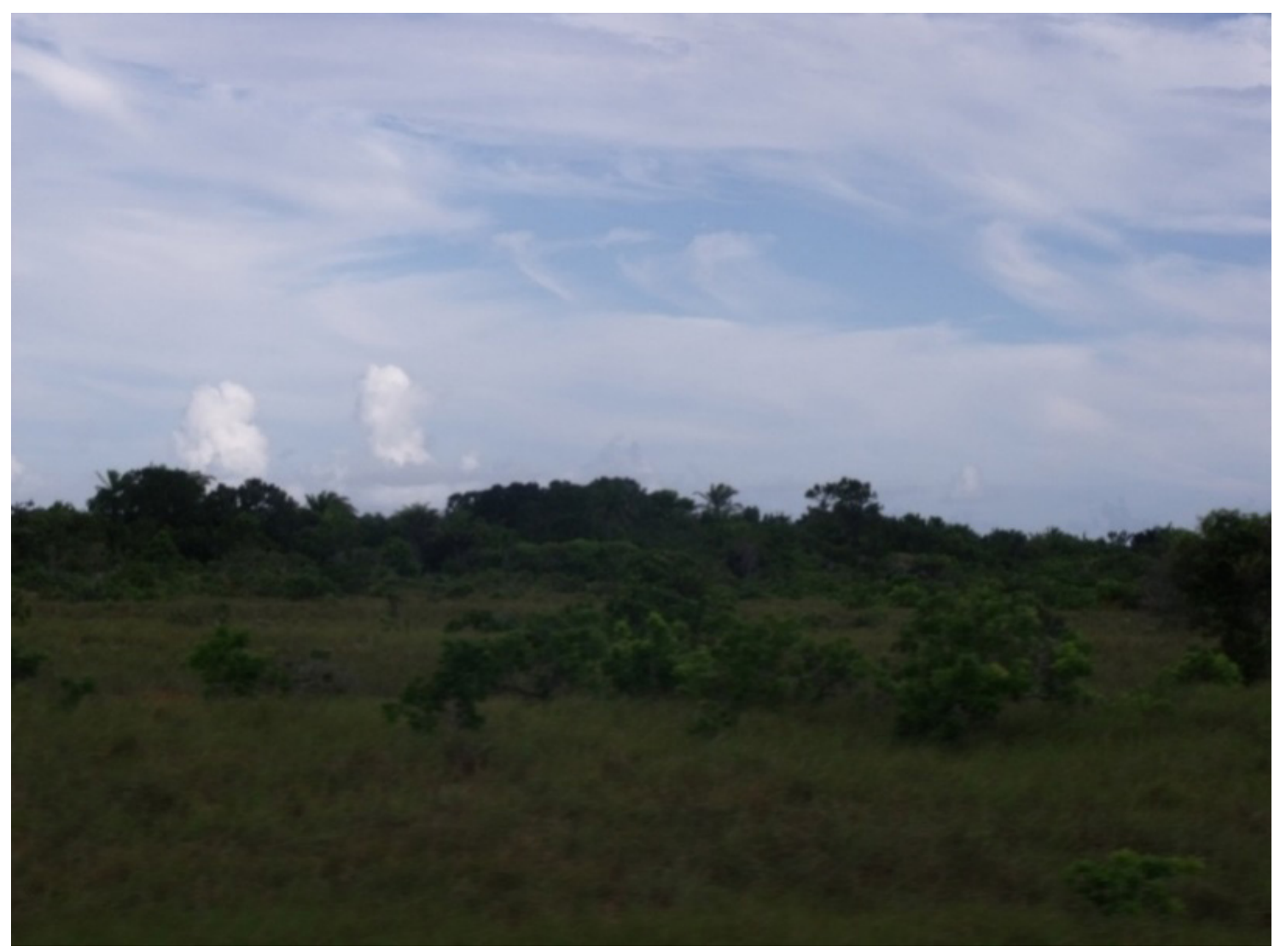

Fonte: Trabalho de campo (junho/2015) 
Por fim, o último Geossistema das áreas de Depósitos Sedimentares Quartanários estão situados nas Planícies Fluviomarinhas que correspondem às acumulações de origem fluviomarinha que compõem as feições morfológicas características da faixa litorânea e que englobam os complexos deltaicos e estuarinos, em algumas áreas mantendo relação direta com falésias. A ação das ondas, correntes e marés provocam uma intensa abrasão e inundações nas áreas deltaicas. Estes fatores determinam a predominância dos processos de erosão e acumulação sobre os de alteração e formação dos solos (BRASIL, 1987).

As fisionomias na paisagem individualizadas nas Planícies Fluviomarinha apresentam menor extensão territorial, se comparadas às Planícies Fluviais. As Planícies Fluviomarinhas representam cerca de $1 \%$ da área total da região Costa do Descobrimento, com área de $64,751 \mathrm{~km}^{2}$. Esses Geossistemas só se desenvolveram nas Bacias Hidrográficas dos Rios Buranhém, Caraíva, Corumbau, Jequitinhonha, João de Tiba (Figuras 7A e B). Jucuruçu, Mogiquiçaba, Queimado, Santo Antônio, Barra e do Frade.

Figura 7 - (A) Planície Fluviomarinha do Rio João de Tiba, Porto Seguro (BA) - imagem do Google Earth (14/06/2015). (B) Planície Fluviomarinha do Rio João de Tiba,Porto Seguro (BA).
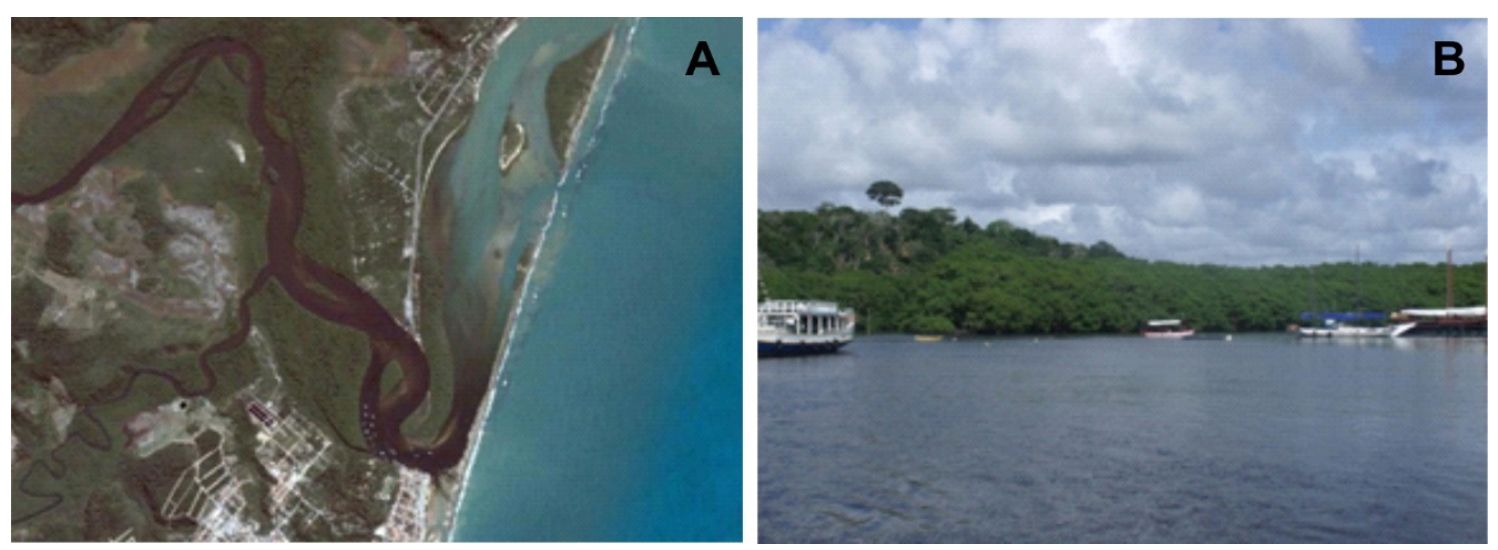

Fonte: (A) Google Earth-Pro (2015); (B) Trabalho de Campo (junho/2015).

Dentre as principais características desses geossistemas, destacam-se as declividades inferiores a $2 \%$, onde se instalaram processos pedogenéticos que formaram os Gleissolos Sálicos bordejados por Neossolos Quartzarênicos e os EspodossolosHidromórficos. Outra característica deste Geossistema é a presença da vegetação de Mangue, é constituída pelas áreas sob influência das oscilações das marés, normalmente com Gleissolos, que ocupam o estuário de certo rios. Desenvolve-se sobre esses solos uma comunidade seral arbórea (Mangue), cujas espécies mais frequentes são bastante homogêneas, repetindose ao longo de todo o litoral brasileiro. O mangue-vermelho (Rhizophoramangle) instalase preferencialmente próximo à desembocadura dos rios, ou seja, em locais com maior grau de salinidade, formando densos povoamentos, cujos indivíduos mais altos atingem 
em torno de $13 \mathrm{~m}$. Já o mangue-branco (Laguncularia racemosa) e o mangue-amarelo (Avicenniagerminans) estendem-se pelos baixos cursos dos rios, atingindo grandes distâncias (BRASIL, 1987).

Nos Domínios Morfoestruturais Depósitos Sedimentares Terciários a feição geomorfológica predominante são os Tabuleiros Costeiros. Os Tabuleiros Costeiros são as áreas emissoras de matéria e energia, pois a maior parte dos canais de primeira ordem nasce nos topos planos dos Tabuleiros, e também nas áreas transmissoras de matéria e energia, pois os sedimentos daFormação Barreiras depositam-se nos fundos de vale, na porção interior, e na linha de costa, nas áreas de falésias ativas (Figura 8 A e B). Corresponde a $5.029,339 \mathrm{~km}^{2}$, o que representa quase $67 \%$ da área total da Região Costa do Descobrimento. Neste domínio morfoestrutural, delimitaram-se três (03) Geossistemas (Figura 3).

Figura 8 - (A) Imagem de Satélite com Falésias na Bacia do Rio Taípe, Porto Seguro (BA) - imagem do Google Earth (14/06/2015); (B) Solapamento da base da falésia situada na Bacia do Rio Taípe, Porto Seguro (BA).
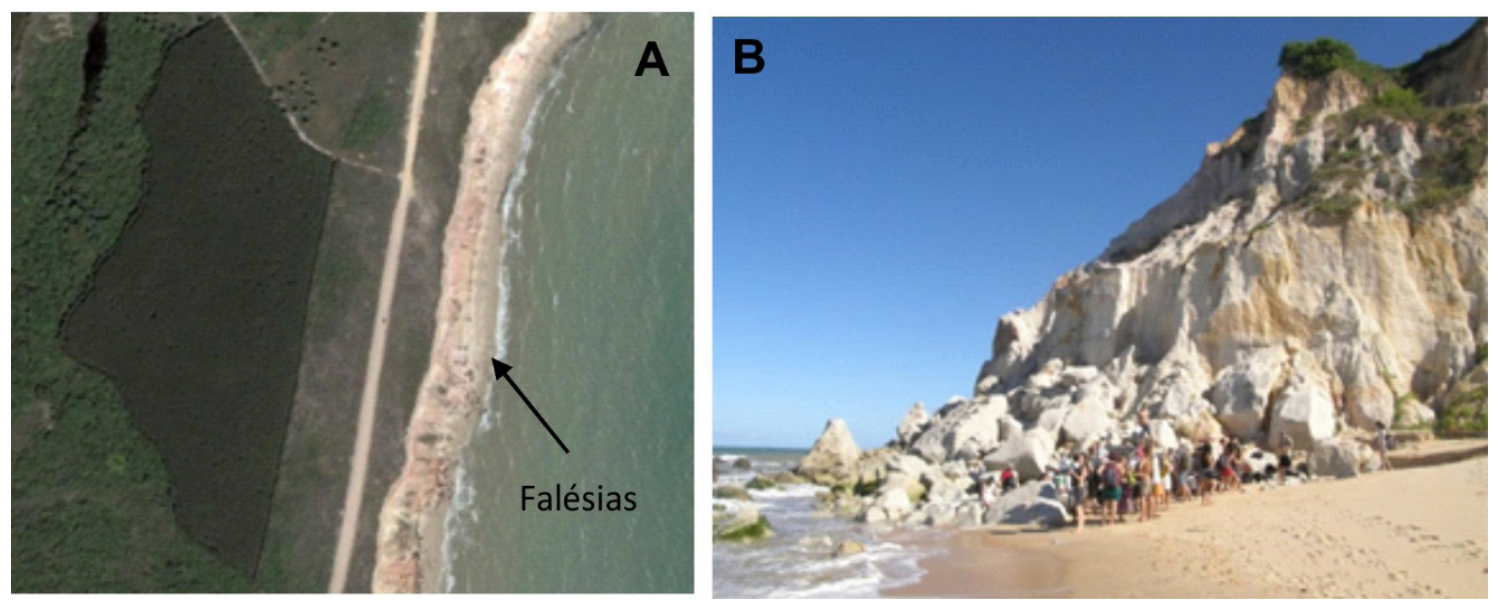

Fonte:(A) Google Earth-Pro (2015); (B)Trabalho de Campo (junho/2015).

Os Tabuleiros Costeiros coincidem com os sedimentos cenozóicos daFormação Barreiras, constituídos de areias e argilas variadas com eventuais linhas de pedra, dispostas em camadas com espessura variável de conformidade com as ondulações do substrato rochoso, que ocasionalmente afloram influenciando nas formas do modelado (TRICART e SILVA, 1968).

Os processos desencadeadores da Formação Barreiras datam do fim do Plioceno. Nesse período, a existência de um clima semiárido, com chuvas esporádicas e violentas associadas a uma fase de soerguimento continental (GHIGNONE, 1979), favoreceu a erosão do importante manto de intemperismo que se teria desenvolvido sobre as rochas do embasamento durante um longo período úmido anterior. 
O material erodido, constituído de sedimentos areno-argilosos pobremente selecionados, acumulou-se no sopé das encostas sob a forma de uma extensa planície aluvial. Nessa época, a regressão marinha permitiu a extensão dessa deposição à plataforma continental (BIGARELLA e ANDRADE, 1964).

Atualmente, a Formação Barreiras distribui-se desde o sopé das elevações cristalinas do Planalto Pré-Litorâneo até as planícies quaternárias, em contato localmente estabelecido por paleofalésias ou por falésias atuais, quando se estendem até a atual linha de costa, como ocorre ao sul de Porto Seguro e ao norte de Prado. É caracterizada pela predominância de feições aplainadas, parcialmente conservadas, submetidas a retoques e remanejamentos sucessivos. Essas feições resultam de uma dissecação fluvial em função de diferentes níveis de bases dados por numerosos rios. Dentre eles, destacam-se os rios Buranhém, Caraíva, Curumbaú, que apresentam um padrão de drenagem paralelo e subparalelo, relacionado com o controle tectônico (GONÇALVES, 1976; ROCHA FILHO, 1976).

As formações superficiais são representadas, predominantemente por colúvios pedogeneizados e materiais de alteração, que correspondem aos Latossolos Amarelos Distróficos, Latossolo Vermelho-Amarelo Distrófico e Argissolos Amarelos Distróficos de textura argilosa e argilo-arenosa. Sobre este modelado também são encontradas manchas de EspodossolosHidromórficos (SANTANA et al, 2002). Moreau (2001) levanta algumas hipóteses para a ocorrência de Espodossolos associados a Latossolos Amarelos em Tabuleiros Costeiros. Dentre elas, a autora destaca: a) desenvolvimento a partir de material das fácies de granulometria grosseira do próprio Barreiras; b) deposição de material arenoso do quaternário sobre o Barreiras; c) acidólise com destruição de argila e erosão do material mais arenoso para a parte abaciada, com posterior formação do Espodossolo.

Sobre os Espodossolos desenvolvidos nos Tabuleiros Costeiros configura-se um Geossistema peculiar, onde se desenvolve uma vegetação rasteira conhecida regionalmente como "Mussunungas" (Figura 9). Essas areias quartzosas apresentam coloração branca a cinzenta. O tamanho do grão varia de areia fina a muito grossa, com grânulos e seixos de quartzo subordinados, além de minerais pesados e horizontes ricos em matéria orgânica. Frequentemente, sob a camada superficial arenosa, ocorre um horizonte areno-argiloso marrom escuro a preto, endurecido, responsável pela retenção das águas pluviais (CBPM, 2000).

Os processos morfogenéticos dos Tabuleiros Costeiros estão diretamente relacionados à elevada umidade do litoral, aliada a declividades muito baixas (inferiores a $5^{\circ}$ ), somada ao escoamento freático que permanece em nível mais elevado, e de escoamento superficial lento. 
Figura 9 - Mussurungassituadas sobreEspodossolosHidromórficos do topo dos Tabuleiros Costeiros, Prado (BA). - imagem do Google Earth (14/06/2015).

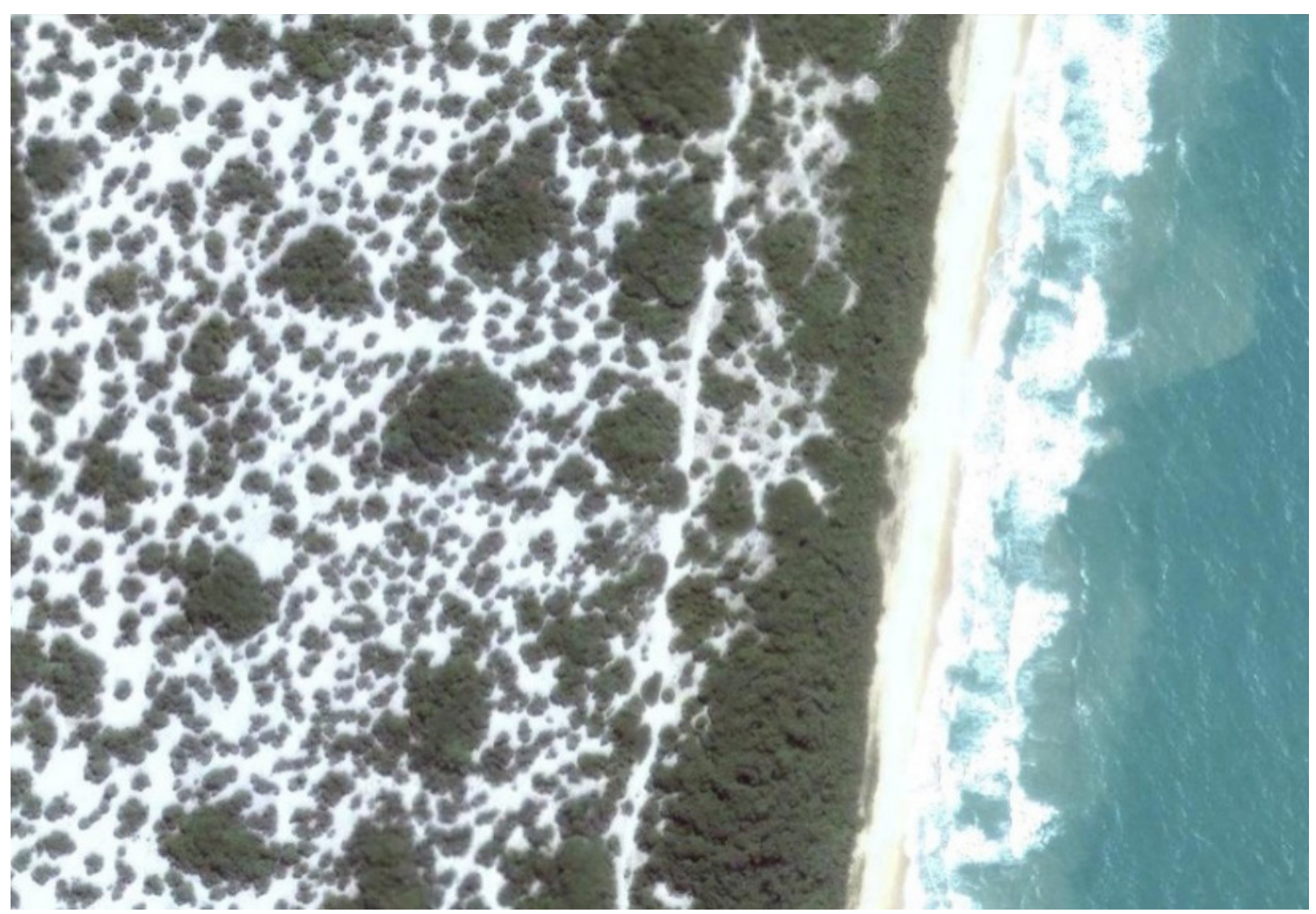

Fonte: Google Earth-Pro (2015);

Nessas áreas, os processos morfogenéticos atuam com maior intensidade, provocando nas encostas uma erosão regressiva, facilitada também pelas propriedades do material e quantidade elevada de chuva. Outro processo morfogenético de ação antrópica é a extração mineral realizada em túneis nas encostas, que cria pontos de fraqueza, nos quais se instalam os processos erosivos e/ou movimentos de massa. Os movimentos de massa na região estão diretamente ligados a instabilidade do material exposto nas escarpas dos Tabuleiros Costeiros, que, em períodos com maior pluviosidade, deflagram os escorregamentos em decorrência da saturação da capacidade de absorção do material, associada às acentuadas declividades. O material retirado, em ambos os casos, é remanejado para a colmotagem dos vales. Assim, a cobertura vegetal, elevada umidade do litoral, a predominância de solos bem desenvolvidos e um modelado que não representa essencialmente obstáculos à sua utilização são características indicativas de uma relativa estabilidade morfodinâmica moderada (BRASIL, 1987).

É possível identificar uma transição entre a Mata Atlântica e a vegetação de Restinga. Analisando essas áreas a partir dos Tabuleiros Costeiros, em direção à linha de maré 
mais alta, observa-se que à medida que os solos vão adquirindo uma cobertura arenosa, a Mata Atlântica vai perdendo sua pujança, com árvores passando a ter um aspecto mais xeromorfizado, até atingir solos totalmente arenosos (Neossolos Quartzarênicos), definindo a formação da vegetação de Restinga em estrato arbóreo (BRASIL, 1987).

No Domínio Morfoestrutural Maciços Cristalinos Proterozóicos, delimitaram-se quatro (04) Geossistemas (Figura 3), sendo que três (03) Geossistemas desenvolvem-se em colinas, morrotes e escarpas de borda de planalto, e um (01) nas áreas limitiformes entre os Maciços Cristalinos Proterozóicos e os Depósitos Sedimentares Terciários (Figura 3).

Estudos realizados para o mapeamento geológico do Estado da Bahia, proposto por Barbosa e Dominguez (1996), consideraram os gnaisses kinzigíticos e gnaisses migmatíticos como pertencentes ao cinturão Itabuna, tido como integrante do embasamento arqueanopaleoproterozóico do cráton do São Francisco. Podem-se destacar as rochas metamórficas dos Complexos Gnáissico-Granítico do Proterozóico inferior, o Complexo Kinzigítico, Grupo Macaúbas e o Granito Água Branca, e também as Rochas Metassedimentares do Grupo Rio Pardo, compartimentadas nas Formações Santa Maria Eterna, Serra do Paraíso, e Água Preta.

O predomínio de rochas metamórficas presentes na área corresponde a litologias do grupo Macaúbas e dos complexos Gnáissico-Granítico e Kinzigítico. Os elementos estruturais mais proeminentes são falhas/fraturas com direções noroeste-sudeste e nordeste-sudoeste, algumas delas projetando-se no contexto das coberturas terciárias daFormação Barreiras. As foliações medidas são raras. Na parte oeste da área, elas têm direção preferencial noroeste-sudeste, com mergulhos fortes para nordeste.

Já na parte noroeste, os traços dos planos $S$ têm direção próxima a norte-sul, com inflexões para noroeste e nordeste. Localmente, a cerca de $1 \mathrm{~km}$ a oeste de Barrolândia, no extremo norte do município de Santa Cruz Cabrália, em quartzitos do grupo Macaúbas, pode-se observar o paralelismo entre essa foliação e o acamamento primário (SO), ambos em padrão assimétrico. Mais a sul, a nordeste de Vera Cruz e ainda no contexto dessa unidade estratigráfica, rochas xistosas mostram uma conspícua clivagem de crenulação (CPRM, 2000).

No extremo sudoeste da área, onde ocorrem exclusivamente gnaisses kinzigíticos, as falhas/fraturas exibem as mesmas direções nordeste-sudoeste e noroeste-sudeste. A foliação de plano axial, quando observada, encontra-se paralelizada ao acamamento (SO), que é definido pela alternância de bandas composicionalmente distintas (félsicas, quartzofeldspáticas e máficas, ricas em minerais ferromagnesianos), como também pela presença de camadas de rochas calcissilicaticas. Nessa região, os traços de foliação desenham formas encurvadas, que sugerem a presença de dobramentos mais recentes (CBPM, 2000). 
As formas predominantes neste complexo litológico são as colinas e os morrotes, que fazem limite com áreas serranas e com vales escavados pela ação da drenagem, onde, por consequência da dissecação do modelado, ocorrem afloramentos nas escarpas e nos fundos de vale.

O outro grupo de rochas proterozóicas presentes na área em estudo, as rochas metassedimentares do Grupo Rio Pardo, situam-se predominantemente no município de Belmonte.

A Formação Água Preta aflora na parte centro-leste de Belmonte, coberta parcialmente por sedimentos terciários daFormação Barreiras. Limita-se com a Formação Santa Maria Eterna, via contato aproximado, e por falha com a do Granito Água Branca. Esta litologia apresenta como modelado predominante o relevo colinoso a levemente serrano e o padrão de drenagem detríticos. O produto do intemperismo químico dessas rochas dá origem a sedimentos argilosos. As principais exposições visitadas encontram-se na estrada Santa Maria Eterna-Boca do Córrego.

A Formação Serra do Paraíso restringe-se, na área estudada, ao vértice extremo noroeste, onde foram observados alguns poucos afloramentos, de pequena expressão, parcialmente cobertos por sedimentos terciários da Formação Barreiras.

A Formação Santa Maria Eterna tem suas melhores exposições nos arredores da localidade homônima. Ocupa grande superfície na parte oeste da área estudada, em contato com a Formação Água Preta e com o Granito Água Branca. Num trecho desta formação geológica desenvolve-se a depressão do Rio Pardo, uma área mais rebaixada, situada entre os Tabuleiros Costeiros daFormação Barreiras, de idade Terciária e as Serras do Grupo Rio Pardo de Idade Proterozóica.

Associadas ao Grupo Rio Pardo, predominam Escarpas e Cristas com encostas convexas que constituem uma superfície intensamente dissecada e rampeada em direção à costa, registrando altitudes médias em torno de $350 \mathrm{~m}$.

Estas unidades encontram-se submetidas às influencias de climas predominantemente úmidos, que interferem nos processos de dissecação e na pedogênese do material superficial. $\mathrm{Na}$ área encontram-se profundos mantos de alteração, favoráveis à evolução de solos profundos, desenvolvidos a partir de rochas proterozóicas, constituídas principalmente de metaxistos, granitos, biotita xistos, quartzo-biotita xistos a gnaisses e também de coberturas detríticas cenozóicas daFormação Barreiras (BRASIL, 1987; SEI, 2004). 
No domínio das Colinas e Morrotes predominam rochas do Complexo GnáissicoGranítico e do Complexo Kinzigítico, enquanto que no domínio das Escarpas e Cristas com encostas convexas, predominam rochas do Grupo Macaúbas e do Grupo Rio Pardo, datadas do Proterozóico superior (CBPM, 2000).

As condições morfogenéticas caracterizadas pelas ações químicas e pela intensidade da dissecação fluvial camuflam os traços estruturais que se refletem na orientação da drenagem, em direção noroeste-sudeste, sugerindo fraturas e falhas. Há segmentos de canais retilíneos ou eventualmente marcados por angulosidades; de margens posicionadas em diferentes níveis, constituindo vales dissimétricos. Observam-se bordas desniveladas em relação aos Tabuleiros Costeiros; e também pontões e cristas relacionadas às rochas do embasamento arqueano (GONÇALVES, 1976; ROCHA FILHO, 1976; BRASIL, 1987).

As encostas mostram-se geralmente convexas, apresentando declividades em torno de 2 a $11 \%$, acusando índices mais fortes em torno de $24 \%$ e até áreas mais elevadas, onde os entalhes são mais profundos. Entremeando-se a estas feições, ocorrem formas aguçadas, resultantes de dissecação diferencial, relacionadas às rochas do embasamento, que ocasionalmente afloram em alguns trechos próximos das drenagens e nos pontões, linhas de cumeadas e cristas, que se destacam das elevações residuais. Os topos dessas feições mostram-se geralmente concordantes com relevos da unidade adjacente. As formas semiconservadas correspondem a restos de coberturas detríticas cenozóicas do Grupo Barreiras, que constituem topos nivelados dissecados por vales que apresentam controle estrutural. Essas coberturas alcançam 3 a $4 \mathrm{~m}$ de espessura, mostrando-se predominantemente grosseiras, formando na base cerca de $1 \mathrm{~m}$ de conglomerado ferrífero. Sua origem deve-se provavelmente à remobilização do material de alteração das rochas do embasamento, cuja deposição é supostamente anterior ao escavamento dos vales, constituindo ainda colúvios de cor avermelhada sobre a rocha alterada, apresentando geralmente linhas de seixos na base. Observa-se ainda que os domínios geomorfológicos apresentam elevada susceptibilidade a processos erosivos (BRASIL, 1987).

Sobre as formas abordadas anteriormente, encontra-se a Mata Atlântica. A mata formada em grande parte por indivíduos de regeneração arbórea dominante, distribui-se espaçadamente, permitindo, até certo ponto, uma fácil locomoção no interior da floresta. As lianas e epífitas não são abundantes e praticamente inexiste um tapete gramíneo-lenhoso baixo (BRASIL, 1987).

Já a Mata Atlântica na área está situada na área onde o clima apresenta duas estações definidas, uma chuvosa e outra seca. Este clima acarreta uma estacionalidade foliar 
dos elementos arbóreos dominantes, os quais têm adaptações à deficiência hídrica. A porcentagem das árvores caducifólias no conjunto florestal e não das espécies que perdem folhas individualmente deve situar-se em torno de $20 \%$ na época desfavorável. A área é caracterizada por um período seco, que varia de 90 a 120 dias, em áreas dissecadas do PréCambriano e umas poucas do Quaternário Recente (aluviais), em altitudes variáveis entre 200 e 500 m. Via de regra, a classe de solo dominante é Argissolo Vermelho-Amarelo, com grande capacidade de retenção de água, o que permite em alguns locais uma amplitude maior do período de estiagem (BRASIL, 1987)

O domínio das Colinas e Morrotes abrange apenas 6,5\% da área total da Região Costa do Descobrimento. Nestes domínios recobertas pela Mata Atlântica Primária e Secundária, as encostas encontram-se cobertas pela mata em estado nativo, como no entorno do Parque Nacional Monte Pascoal, ou em estágio de regeneração.

Definiram-se dois Geossistemas no limite entre o Planalto Costeiro e o Planalto PréLitorâneo, onde a presença de Escarpas e Cristas, intercaladas por colinas com encostas convexas associadas a processos a variação da pluviosidade, desenvolve solos nas áreas mais aplainadas, com maior umidade, associados a processos de hidratação de minerais de argila, formando Latossolos e Argissolos Amarelos. Por outro lado, nas áreas em que há predomínio dos processos de translocação de argila ocorre a gênese dos Argissolos Vermelhos e Latossolos Vermelhos com Mata Atlântica, que se situam nas bacias dos Rios Jequitinhonha e Pardo. Nas áreas mais rebaixadas de vales encaixados, podem ocorrer inundações periódicas. Apresentam essas áreas baixo potencial de uso econômico, mantendo assim um grau de estabilidade bastante significativo. Adjacente a essas áreas, desenvolve-se nos setores de encosta e nas áreas de topo, a cobertura de Mata Atlântica Primária e Secundária como ilustra a Figura 10 A e B. 
Figura 10 - (A) Colina com Argissolos Vermelho-Amarelo situada na Depressão Bacia do Rio Pardo, Belmonte (BA); (B) Serras da Bacia do Rio Jequitinhonha, Belmonte (BA).
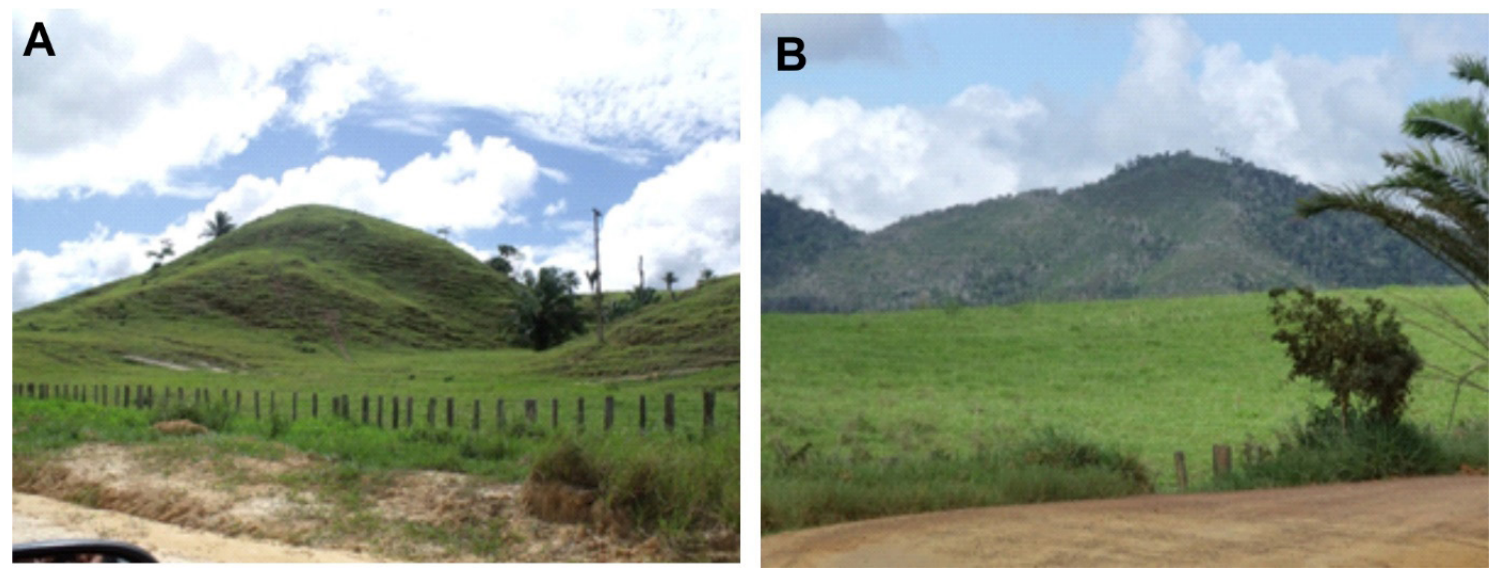

Fonte: Trabalho de campo (junho/2015).

A dinâmica desses Geossistemas está sendo alterada pela ação antrópica, pois a cobertura vegetal natural vem sendo substituído por pastagens e por atividades agrícolas, o que ocasiona alteração nos fluxos de matéria e energia dos sistemas, principalmente a energia da gota da chuva sobre o solo, agora exposto ou com uma vegetação rasteira, facilitando a ocorrência dos processos erosivos.

\section{CONSIDERAÇÕES FINAIS}

A representação espacial dos Geossistemas é de suma importância para estudos no campo da Geografia Física. A Geografia Russo-Soviética tem muito a contribuir no aprimoramento da metodologia de estudo integrado dos componentes físico-naturais numa perspectiva sistêmica.

No caso do mapa de paisagens, a metodologia adotada pode ser aplicada em qualquer escala. O nível de detalhe representado no mapa de paisagens corresponde à escala de detalhe dos elementos (subsistemas) correlacionados para a delimitação dos mesmos. Quanto maior o nível de detalhe do mapeamento temático que será correlacionado como subsistemas dos diferentes Geossistemas, mais eficazmente será possível representar unidades geossistêmicas com complexidade estrutural do tipo processo-resposta, podendo numa escala de detalhe, identificar e analisar as estocagens, fluxos e outros processos, a fim de obter conhecimento detalhado e claro de como a estrutura interna do sistema funciona. Isso possibilita transformar um input em output (caixa branca), e, no caso de 
uma escala de detalhe mais generalizante, a delimitação dos Geossistemas irá envolver o conhecimento parcial do funcionamento do sistema quando o interesse se centralizar apenas em um número limitado de subsistemas, não se considerando as suas operações internas (caixa cinza).

O advento das geotecnologias, em especial os softwares de sistemas de informação geográfica, aprimora a integração de dados geográficos georreferenciados, que no passado, eram feitos a partir da sobreposição analógica de cartas temáticas.

Considerando a diversidade de litologias, a complexidade na disposição das formas de relevo e classes de solos, bem como as variações da cobertura vegetal decorrentes de alterações do regime pluviométrico e das temperaturas, é necessário elaborar legendas que possibilitem a leitura e interpretação de cada Geossistema por seus leitores, não só a partir do uso de geotecnologias, mas também por meio do mapa impresso, dando subsídio a leitura do ambiente em campo.

A delimitação dos Geossistemas em escala regional apresenta um número limitado de sistemas naturais; entretanto, dá suporte para ações de planejamento em escala regional, pois possibilita conhecer dinâmica e fragilidades, além de mitigar problemas ambientais associados ao uso e ocupação das terras, principalmente na Região Costa do Descobrimento, onde os empreendimentos voltados ao turismo e a indústria de celulose que extrapolam o limite municipal, alteram toda a dinâmica de circulação de matéria e energia na região.

Outro ponto a ser constatado é que o mapeamento também pode subsidiar novos estudos em recortes específicos, ampliando a escala de análise e consequentemente realizar uma análise detalhada da estrutura interna do sistema.

\section{REFERENCIAS}

1. AMORIM, R. R. Análise Geoambiental como subsídio ao uso e ocupação das terras da Região Costa do Descobrimento (Bahia). 2011. 283p. (Doutorado em Geografia), Universidade Estadual de Campinas, Campinas. 2011.

2. AMORIM, R. R. Um novo olhar na Geografia para os conceitos e aplicações de Geossistemas, Sistemas Antrópicos e Sistemas Ambientais. Revista Caminhos de Geografia (UFU). v. 13, 2012. 80-101p.

3. AMORIM, R. R.; OLIVEIRA, R. C. Zoneamento ambiental, subsídio ao planejamento no uso e ocupação das terras da costa do descobrimento. Mercator, Fortaleza, v. 12, n. 29, p. 211 231, set./dez. 2013. 
4. BERTRAND, G. Paisagem e Geografia Global. Esboço metodológico. São Paulo: Universidade de São Paulo, Instituto de Geografia, Cadernos de Ciências da Terra, (13) p. 1-27.

5. BIGARELLA, J.J., ANDRADE, G.O. Considerações sobre a estratigrafia dos sedimentos cenozóicos em Pernambuco (Grupo Barreiras). Arquivo do Instituto de Ciências da Terra. Recife, n. 2, 1964. p. 2-14.

6. BRASIL. Folha SE 24 Rio Doce: geologia, geomorfologia, pedologia, vegetação, uso potencial da terra. IBGE. Rio de Janeiro, 1987.

7. CAVALCANTI, L. C. S. et al. Técnicas de campo para descrição de geossistemas: reconhecimento expedito na borda oeste de maciço residual de Poço das Trincheiras, Alagoas. Geoambiente on-line. v.15, 2010. p. 72-102.

8. CAVALCANTI, L. C. S. Geossistemas do Estado de Alagoas: uma contribuição aos estudos da natureza em Geografia. 2010. 132p. (Mestrado em Geografia). Universidade Federal de Pernambuco, Recife. 2010.

9. CAVALCANTI, L. C. S. Da abordagem de áreas à teoria dos Geossistemas: uma abordagem epistemológica sobre sínteses naturalistas. 2013. 218p. (Doutorado em Geografia). Universidade Federal de Pernambuco, Recife. 2013.

10. CAVALCANTI, L. C. S.; CORRÊA, A. C. B.; ARAUJO FILHO, J. C. Geosystemsof Alagoas State. Regional Conference onGeography - Internacional Geographic Union. Santiago. Chile. 2011. 1-15p.

11. CAVALCANTI, L. C. S.; CORRÊA, A. C. B.; ISACHENKO, G. A. Contribuição ao estudo de geossistemas no Brasil. Anais do $\mathbf{1}^{\mathbf{0}}$. Congresso Brasileiro de Organização do Espaço. Rio Claro, 2010. 1-15p.

12. CBPM. Companhia Baiana de Recursos Minerais. Projeto Costa do Descobrimento. Salvador: CBPM, 2000. (CD-ROM).

13. CHRISTOFOLETTI, A. Geomorfologia. 2 ed. São Paulo: Edgar Blücher, 1980.

14. CPRM. Companhia Brasileira de Recursos Minerais. Projeto Porto Seguro - Santa Cruz Cabrália. Brasília: Serviço Geológico do Brasil, 2000. v. 1-8.

15. GHIGNONE, J. I. Geologia dos sedimentos fanerozóicos do estado da Bahia. In: INDA, H. (Ed.). Geologia e recursos minerais do estado da Bahia. Salvador: CPM, 1979. (Textos básicos, v.1). p.24-117.

16. GONÇALVES, E. Geologia e Recursos Minerais. Rio de Janeiro: Cartográfica Cruzeiro do Sul, 1976. 142p. (Diagnóstico socioeconômico da região cacaueira).

17. GUERRA, A. J.; GUERRA, A. J. T. Dicionário geológico-geomorfológico. 5 ed. Rio de Janeiro: Betrand Brasil, 2005.

18. HOEFEL, F. G. Morfodinâmica de praias arenosas oceânicas: uma revisão bibliográfica. Itajai :Univali, 1998.

19. ISACHENKO, A. G. Principles of Landscape Science and physical-geographic regionalization. Melbourne: Melbourne University Press. 1973. 
20. MOREAU, A. M. S. S. Gênese, mineralogia e micromorfologia de horizontes coeso, fragipã e duripã em solos do tabuleiro costeiro do sul da Bahia. 2001. 194p. (Doutorado em Solos e Nutrição de Plantas), Universidade Federal de Viçosa, Viçosa. 2001.

21. MUEHE, D. Geomorfologia Costeira. In: GUERRA, A. J. T.; CUNHA, S. B. (org.) Geomorfologia: uma atualização de bases e conceitos. Rio de Janeiro: Bertrand Brasil, 2001. 253-308p.

22. RICE, R. J. Fundamentos de Geomorfologia. Madrid : Paraninfo, 1983.

23. ROCHA FILHO, C. A. Recursos Hídricos. Rio de Janeiro: Convênio II RA / Ceplac, 1976. (Diagnóstico socioeconômico da região cacaueira).

24. RODRIGUEZ, J. M. M.; SILVA, E. D.; CAVALCANTI, A. P. B. Geoecologia da paisagem: uma visão geossistêmica da análise ambiental. Fortaleza: EDUFC, 2004.

25. ROSS, J. L. S. Geomorfologia, ambiente e planejamento. São Paulo:Contexto, 1990. (Coleção Repensando a Geografia).

26. SANTANA, S. O. et al. Solos da região Sudeste da Bahia: atualização da legenda de acordo com o sistema brasileiro de classificação de solos. Ilhéus: CEPLAC; Rio de Janeiro: Embrapa Solos, 2002. CD-ROM.

27. SEI. Superintendência deEstudos Econômicos e Sociais da Bahia. Balanço Hídrico do Estado da Bahia. Salvador: SEI, 1999.

28. SEI. Superintendência de Estudos Econômicos e Sociais da Bahia. Mapas digitalizados do Estado da Bahia: base de dados. Salvador: SEI, 2004. (CD-ROM).

29. SILVA, L. F. Aptidão agrícola dos solos da região da região cacaueira. Rio de Janeiro: Cartografia Cruzeiro do Sul, 1975. (Diagnóstico socioeconômico da região cacaueira).

30. SOCHAVA, V. B. GeographyandEcology.SovietGeography, v.12, n.:5, pp. 277-293, 1971.

31. SOCHAVA, V. B. Theoretical requisites for the mappingofthehuman habitat.SovietGeography, v.16, n.:2, pp. 86-98, 1975.

32. SOCHAVA, V. B. O Estudo de Geossistemas. Métodos em questão, 16. IG-USP. São Paulo, 1977.

33. SOCHAVA, V. B. Por uma teoria de classificação de geossistemas de vida terrestre.Biogeografia. IG-USP. São Paulo, 1978.

34. SOCHAVA, V.B.; KRAUKLIS, A. A.;SNYTKO, V.A. Toward a unificationofconceptsandtermsused in integral landscapeinvestigations.SovietGeography, v.16, n.:9, pp. 616-622, 1975.

35. SOS Mata Atlântica 2008. Atlas dos remanescentes florestais da Mata Atlântica, período de 2012 a 2014. Disponivel em: <https://www.sosma.org.br/wp-content/uploads/2014/05/ atlas_2012-2013_relatorio_tecnico_20141.pdf >. Acesso em: 15/01/2015.

36. SUDENE. Superintendência de Desenvolvimento do Nordeste. Folha Canavieiras (SD-24-ZC-IV). Bahia, SUDENE, 1977a. Escala 1:100.000.

37. SUDENE. Superintendência de Desenvolvimento do Nordeste. Folha Guaratinga (SE-24VB-V). Bahia, SUDENE, 1977b. Escala 1:100.000. 
38. SUDENE. Superintendência de Desenvolvimento do Nordeste. Folha Itamaraju (SE-24-VDII). Bahia, SUDENE, 1977c. Escala 1:100.000.

39. SUDENE. Superintendência de Desenvolvimento do Nordeste. Folha Mascote (SD-24-YDVI). Bahia, SUDENE, 1977d. Escala 1:100.000.

40. SUDENE. Superintendência de Desenvolvimento do Nordeste. Folha Monte Pascoal (SE-24V-B-VI). Bahia, SUDENE, 1977e. Escala 1:100.000.

41. SUDENE. Superintendência de Desenvolvimento do Nordeste. Folha Porto Seguro (SE-24V-B-III). Bahia, SUDENE, 1977f. Escala 1:100.000.

42. SUDENE. Superintendência de Desenvolvimento do Nordeste. Folha Potiraguá (SD-24YD-V2). Bahia, SUDENE, 1977g. Escala 1:100.000.

43. SUDENE. Superintendência de Desenvolvimento do Nordeste. Folha Prado (SE-24-V-DIII). Bahia, SUDENE, 1977h. Escala 1:100.000.

44. SUDENE. Superintendência de Desenvolvimento do Nordeste. Folha Salto da Divisa (SE-24V-B-II). Bahia, SUDENE, 1977i. Escala 1:100.000.

45. SUDENE. Superintendência de Desenvolvimento do Nordeste. Folha Santo André (SE-24X-A-I). Bahia, SUDENE, 1977j. Escala 1:100.000.

46. SUGUIO, K. Geologia do Quarternário e mudançasambientais. São Paulo: Oficina de Textos, 2010.

47. SUGUIO, K., MARTIN, L. Brazilian Coastline Quaternary formations - the states of São Paulo and Bahia littoral zone evolutive schemes. Anais da Academia Brasileira de Ciências. Rio de Janeiro, v.48, p. 325-334, 1976. Suplemento.

48. TRICART, J.; SILVA, T. C. Estudos de Geomorfologia da Bahia e Sergipe. Salvador: Fundação para o Desenvolvimento da Ciência da Bahia, 1968.

49. VINAGRADOV, B. V.; et al.Basic principlesoflandscapemapping.SovietGeography, v.3, n.6, pp. 15-20, 1962.

\section{AGRADECIMENTOS}

Agradecimento a Fundação de Amparo à Pesquisa do Estado de São Paulo (FAPESP) pelo financiamento do projeto de pesquisa.

Artigo recebido em 4 de fevereiro de 2016. Artigo aceito em 12 de junho de 2016. 